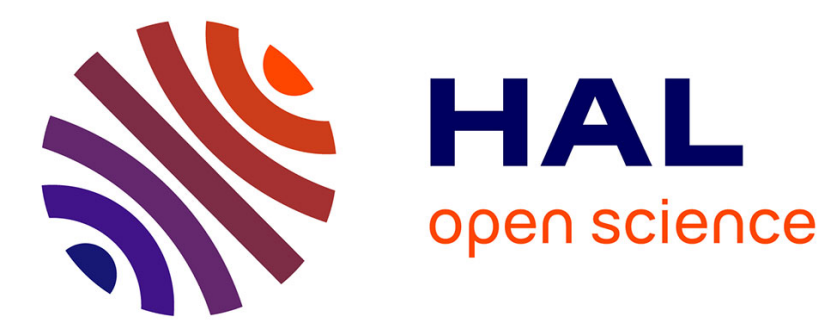

\title{
Udp-Glucuronosyltransferase 1a6 Overexpression In Breast Cancer Cells Resistant To Methotrexate
} M. Cristina De Almagro, Elisabet Selga, Rémi Thibaut, Cinta Porte, Véronique Noé, Carlos J. Ciudad

\section{- To cite this version:}

M. Cristina De Almagro, Elisabet Selga, Rémi Thibaut, Cinta Porte, Véronique Noé, et al.. UdpGlucuronosyltransferase 1a6 Overexpression In Breast Cancer Cells Resistant To Methotrexate. Biochemical Pharmacology, 2010, 81 (1), pp.60. 10.1016/j.bcp.2010.09.008 . hal-00642426

\section{HAL Id: hal-00642426 \\ https://hal.science/hal-00642426}

Submitted on 18 Nov 2011

HAL is a multi-disciplinary open access archive for the deposit and dissemination of scientific research documents, whether they are published or not. The documents may come from teaching and research institutions in France or abroad, or from public or private research centers.
L'archive ouverte pluridisciplinaire HAL, est destinée au dépôt et à la diffusion de documents scientifiques de niveau recherche, publiés ou non, émanant des établissements d'enseignement et de recherche français ou étrangers, des laboratoires publics ou privés. 


\section{Accepted Manuscript}

Title: Udp-Glucuronosyltransferase 1a6 Overexpression In Breast Cancer Cells Resistant To Methotrexate

Authors: M. Cristina de Almagro, Elisabet Selga, Rémi Thibaut, Cinta Porte, Véronique Noé, Carlos J. Ciudad

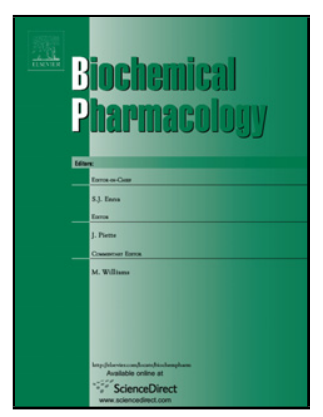

PII:

S0006-2952(10)00664-7

DOI: doi:10.1016/j.bcp.2010.09.008

Reference: BCP 10713

To appear in: $\quad B C P$

Received date: $\quad$ 16-7-2010

Revised date: $\quad$ 7-9-2010

Accepted date: $\quad 9-9-2010$

Please cite this article as: Almagro MC, Selga E, Thibaut R, Porte C, Noé V, Ciudad CJ, Udp-Glucuronosyltransferase 1a6 Overexpression In Breast Cancer Cells Resistant To Methotrexate, Biochemical Pharmacology (2010), doi:10.1016/j.bcp.2010.09.008

This is a PDF file of an unedited manuscript that has been accepted for publication. As a service to our customers we are providing this early version of the manuscript. The manuscript will undergo copyediting, typesetting, and review of the resulting proof before it is published in its final form. Please note that during the production process errors may be discovered which could affect the content, and all legal disclaimers that apply to the journal pertain. 


\title{
UDP-GLUCURONOSYLTRANSFERASE 1 A6 OVEREXPRESSION IN BREAST
}

CANCER CELLS RESISTANT TO METHOTREXATE

\author{
M. Cristina de Almagro ${ }^{a}$, Elisabet Selga ${ }^{a 1}$, Rémi Thibaut ${ }^{b}$, Cinta Porte $^{b}$, Véronique Noé $^{a}$ \\ and Carlos J. Ciudad ${ }^{\mathrm{a}}$ \\ ${ }^{\mathrm{a}}$ Department of Biochemistry and Molecular Biology, School of Pharmacy, University of \\ Barcelona, Av. Diagonal 643, E-08028 Barcelona, Spain. \\ ${ }^{\mathrm{b}}$ Department of Environmental Chemistry, IDAEA-CSIC, c/Jordi Girona 18, E-08034 \\ Barcelona, Spain.
}

Address correspondence to: Ciudad, Carlos J. Department of Biochemistry and Molecular Biology, School of Pharmacy, Av. Diagonal 643, E-08028 Barcelona, Spain. Phone:

+34934034455. Fax: +34934024520; e-mail: cciudad@ub.edu
C.A: cdealmagro@ub.edu
E.S: eselga@gencardio.com
V.N: vnoe@ub.edu
C.C: $\underline{\text { cciudad@ub.edu }}$
R.T: remi.thibaut@gmail.com
C.P: cinta.porte@cid.csic.es

\section{Category: Antibiotics and Chemotherapeutic}




\begin{abstract}
Methotrexate is a chemotherapeutic agent used in breast cancer treatment, but the occurrence of resistance limits its therapeutic use. A microarrays analysis between sensitive and methotrexate resistant MCF7 and MDA-MB-468 breast cancer cells pointed out the UDPglucuronosyltransferase 1A (UGT1A) family as a common deregulated node in both cell lines. This family of genes is involved in Phase II metabolism. UGT1A6 was the main isoform responsible for UGT1A family overexpression in these cells. Its overexpression was not due to gene amplification. Transfection of a vector encoding for UGT1A6 in sensitive cells counteracted the cytotoxicity caused by methotrexate. Methotrexate increased the transcriptional activity from a luciferase reporter driven by the UGT1A6 promoter and induced UGT1A6 mRNA and enzymatic activity. Promoter analysis suggested that UGT1A6 induction by methotrexate could be driven by the transcription factors ARNT (HIF-1) and AhR/ARNT. Cells incubated with anticancer drugs susceptible to glucuronidation, such as tamoxifen or irinotecan, together with methotrexate, showed a lesser degree of cytotoxicity, due to UGT1A6 induction. The pharmacological effect of this induction should be taken into account when combining methotrexate with other drugs that are glucuronidated.
\end{abstract}

Keywords: methotrexate; breast cancer; UGT1A6; microarray; drug resistance. 


\section{INTRODUCTION}

Breast cancer is the most common cancer in women in developed countries, and after lung cancer, the tumour that causes more deaths among females [1]. One of the possible treatments for this cancer is methotrexate (MTX), usually given in combination with cyclophosphamide and 5-flurouracil. MTX is also used in other types of cancer such as acute lymphocytic leukaemia, non-Hodgkin's lymphoma, osteosarcoma, choriocarcinoma, and head and neck cancer; as well as autoimmune diseases as psoriasis and rheumatoid arthritis [2, 3]. However, a major problem of methotrexate, in common with other chemotherapeutic drugs, is the occurrence of drug resistance.

Methotrexate is a folate analogue that reversibly binds to the dihydrofolate reductase (DHFR) enzyme. Dihydrofolate reductase catalyzes the reduction of dihydrofolate to tetrahydrofolate, needed for the synthesis of thymidylate, hypoxantine and glycine [4]. MTX inhibition of DHFR results in the blockage of DNA synthesis and cell growth. Different mechanisms of MTX resistance had been described including $d h f r$ locus amplification, mutation of the target, alteration in the degree of polyglutamation, MDR phenotype, and decreased entrance of the drug [3].

With the aim to get further insight into the mechanisms of MTX resistance, functional genomic analysis using microarrays were performed in breast cancer cell lines sensitive and resistant to MTX. We identified UGT1A as the common gene among the differentially expressed genes in the two breast cancer cell lines resistant to MTX.

UDP-glucuronosyltransferases (UGTs) are a family of enzymes involved in phase II 
metabolism. The addition of a glycosyl group from uridine diphosphoglucuronic acid (UDPGA) renders hydrophobic compounds more soluble for their elimination via bile and urine. UGTs catalyse the glucuronidation of many lipophilic endogenous substrates such as bilirubin and estrogens, and xenobiotics. Anticancer agents such as irinotecan, topotecan, doxorubicin and tamoxifen as well as carcinogens, are glucuronidated, contributing significantly to the overall availability and pharmacological effect of these xenobiotics [5].

The UGT superfamily is divided into families and subfamilies based on protein sequence identity, where UGT1 and UGT2 families share less than 50\% of identity [6]. The UGT1 gene family expresses nine functional UGT1A proteins by alternative splicing of 13 different tandem exons 1 with the common exons 2-5 [7-9]. Thus, all the UGT1A isozymes have a highly conserved "common" region, which is believed to contain the cofactor-binding site, and a variable region containing unique substrate-binding sites. Significant overlap exists in substrate specificity among the UGT family members [10-12]. The UGT1A genes are divided in two clusters, the UGT1A7-10 cluster of genes showing >70\% similar in their first exon sequence and $<60 \%$ similar to the other UGT1A1-6 genes [8].

UGT1A6 metabolizes planar phenols and arylamines. Two types of UGT1A6 formed by alternative splicing have been identified, which differ in the beginning of the first exon [13, 14]. Type 1 has a longer and complete exon 1 and 5'UTR, typical of the UGT1A genes; whereas Type 2 suffers alternative splicing in the 5'UTR, removing part of the beginning of exon 1 and resulting in a shorter isoform. UGT1A6 expression is highly modulated by hormones, drugs, and other xenobiotics that serve as ligands for multiple sensors, including the pregnane $\mathrm{X}$ receptor (PXR), the constitutive androstane receptor (CAR), the aryl hydrocarbon $(\mathrm{AhR})$ receptor, and the transcription factor $\mathrm{Nrf} 2$, which responds to oxidative 
/electrophile stress $[14,15]$.

In this study, the relevance of UGT1A6 overexpression in MTX resistance was analysed in breast cancer cells sensitive and resistant to this drug. Moreover, the induction of UGT1A6 by MTX and the transcription factors involved were studied. 


\section{MATERIAL AND METHODS}

\subsection{Chemicals.}

SN-38 and tamoxifen were purchased from Sigma-Aldrich (Madrid, Spain) and dissolved in DMSO. Methotrexate i/v was purchased from Almirall (Barcelona, Spain).

\subsection{Cell culture.}

MCF7 and MDA-MB-468 (abbreviated in this study as MDA-MB) breast cancer cells were grown in Ham's F-12 medium containing 7\% foetal bovine serum (GIBCO Invitrogen, Barcelona, Spain), and incubated at $37^{\circ} \mathrm{C}$ in a humidified $5 \% \mathrm{CO}_{2}$ atmosphere. MCF7-R and MDA-MB-R were breast cancer cells resistant to $10^{-6} \mathrm{M}$ Methotrexate (MTX), generated in our laboratory upon incubation with stepwise concentrations of MTX, following the methodology previously described in [16]. These cells were 100-fold resistant compared to sensitive cells. These cell lines were grown in Ham's F-12 medium lacking the final products of DHFR activity: glycine, hypoxanthine and thymidine, (-GHT medium, [17]) containing 7\% of dialyzed foetal bovine serum. Cells were detached with $0.05 \%$ trypsin (Sigma-Aldrich, Madrid, Spain).

\subsection{Microarrays.}

Gene expression was analyzed by hybridization to the GeneChip® Human Genome U133 PLUS 2.0 from Affymetrix, containing over 54,000 transcripts and variants. Total RNA for cDNA arrays was prepared from triplicate samples of every sensitive and resistant cell line using RNAeasy Mini kit (Qiagen, Madrid, Spain) following the recommendations of the manufacturer. Labelling, hybridization and detection were carried out following the manufacturer's specifications. The data discussed in this publication have been deposited in 
NCBIs Gene Expression Omnibus [18] and are accessible through GEO Series accession number $\underline{\text { GSE16070 }}$ for MCF7 cells and $\underline{\text { GSE16080 }}$ for MDA-MB-468 cells.

\subsection{Microarray data analyses.}

Gene expression analyses were performed using three samples of both sensitive and resistant cell lines. These analyses were carried out with the GeneSpring GX software v 7.3.1 (Agilent Technologies, Madrid, Spain), using the latest gene annotations available (March 2009). Normalization was applied in two steps: 'per chip normalization', by which each measurement was divided by the $50^{\text {th }}$ percentile of all measurements in its array; and 'per gene normalization', by which all the samples were normalized against the median of the control samples (sensitive cells). The expression of each gene was reported as the ratio of each condition relative to control (sensitive) condition after normalization of the data. Then, data were filtered using the control strength, a control value calculated using the Cross-Gene Error model on replicates [9] and based on average base/proportional value. Measurements with higher control strength are relatively more precise than measurements with lower control strength. Genes that did not reach this value were discarded. Additional filtering was performed to determine differentially expressed genes. A first filter was performed selecting the genes that displayed a $p$ value, corrected by false discovery rate (Benjamini and Hochberg false discovery rate), of less than 0.05 . The output of this analysis was then filtered by fold expression. Thus, lists of genes differentially expressed by at least two fold were generated for each cell line.

\section{5. mRNA analysis.}

Total mRNA was extracted from cells using the Ultraspec ${ }^{\mathrm{TM}}$ RNA Kit (Bioteck, Houston, Texas), according to the manufacturer's specifications. The amount of RNA was determined 
by measuring its absorbance $(260 \mathrm{~nm})$ at $25^{\circ} \mathrm{C}$ in a Nanodrop ND-1000 spectrophotometer. For the induction experiments, mRNA was extracted 24 hours after incubation of 500,000 cells with methotrexate. mRNA was subjected to DNAse treatment to avoid DNA contamination in the PCR step of the RT-PCR analysis. cDNA was synthesized in a $20 \mu \mathrm{l}$ reaction mixture containing $0.2-0.5 \mu \mathrm{g}$ of total RNA, 125 ng random hexamers (Roche, Mannheim, Germany), $10 \mathrm{mM}$ dithiothreitol, 20 units of RNAsin (Promega Biotech Ibérica, Madrid, Spain), 0.5 mM dNTPs (AppliChem, Ecogen, Barcelona, Spain), $4 \mu$ l of 5X RT buffer and 200 units of M-MLV reverse transcriptase (Invitrogen, Barcelona, Spain). The reaction mixture was incubated at $37^{\circ} \mathrm{C}$ for 1 hour. Three $\mu l$ of cDNA mixture were used for PCR amplification by Real Time.

Real Time-PCR: the reaction was performed using the ABI-Prism 7000 Sequence Detection System (Applied Biosystems, Barcelona, Spain). For ugt1a10, the reaction was carried out in a final volume of $20 \mu 1$, containing 1X Taqman Universal PCR Mastermix (Applied Biosystems, Barcelona, Spain), 1X of TaqMan probe (Applied Biosystems, Barcelona, Spain), $3 \mu 1$ of cDNA and $\mathrm{H}_{2} \mathrm{O}$. For ugtla, ugtlal, ugtla3-9, and ugtla6 Type 1 and 2, a Sybr Green PCR reaction was performed in a final volume of $20 \mu 1$, containing 1 X Sybr Universal PCR Mastermix (Applied Biosystems, Barcelona, Spain), 0,25 $\mu \mathrm{M}$ of reverse and forward primers (Ecogen, Barcelona, Spain), $3 \mu \mathrm{l}$ of cDNA and $\mathrm{H}_{2} \mathrm{O}$. Either for the Taqman or the Sybr Green reactions, the adenosylphosphoribosyl transferase (APRT) for mRNA, was used to normalize the results. The primer sequences are listed on Additional Table 1. PCR cycling conditions were $2 \mathrm{~min}$ at $50^{\circ} \mathrm{C}, 10 \mathrm{~min}$ denaturation at $95^{\circ} \mathrm{C}$, followed by 40 cycles of $15 \mathrm{sec}$ at $95^{\circ} \mathrm{C}$ and $1 \mathrm{~min}$ at $60{ }^{\circ} \mathrm{C}$. The mRNA amount of the target gene, normalized to APRT, was given by the $\Delta \Delta C_{\mathrm{T}}$ method, where $\mathrm{C}_{\mathrm{T}}$ is the threshold cycle indicating the fractional cycle number at which the amount of amplified mRNA reached threshold. 


\subsection{UGT copy number determination.}

Genomic DNA from either sensitive or resistant cells was obtained with the Wizard'TM Genomic DNA Purification Kit (Promega Biotech Ibérica, Madrid, Spain) following the manufacturer's recommendations. One hundred ng of DNA were used for Sybr Green Real Time-PCR amplification. Primers used for UGT1A6 and UGT1A4 were the mRNA For and the UGT1A Ex4 Rev primers (listed on Additional Table 1). APRT for DNA was used to normalize the results.

\subsection{UGT1A6 activity assay.}

\subsubsection{Preparation of S9 fractions from cell cultures.}

Cells plated in 100-mm plates were trypsinized, washed with PBS and centrifuged at $800 \mathrm{~g}$ for $5 \mathrm{~min}$. The resulting pellet was resuspended in $300 \mu \mathrm{l}$ of cold potassium-phosphate buffer (100 mM; pH 7.4) and cells were homogenized by sonication. S9 fractions were obtained by centrifugation at $9,000 \mathrm{~g}$ for $20 \mathrm{~min}$ at $4^{\circ} \mathrm{C}$. Protein content of S9 fractions was determined with the Bradford method [19] (Bradford purchased from Sigma-Aldrich, Madrid, Spain) using bovine serum albumin as protein standard.

\subsubsection{UDP-glucuronosyltransferase (UGT) activity.}

UGT activity was measured in S9 fractions prepared from MCF7 and MDA-MB sensitive and resistant cells, using $\left[1{ }^{14} \mathrm{C}\right]-\alpha-$ naphthol (American Radiolabeled Chemical Inc., St. Louis, Missouri) as substrate. S9 fractions ( $125 \mu \mathrm{g})$ were incubated in $50 \mathrm{mM}$ Tris- $\mathrm{HCl}$ buffer $\mathrm{pH}$ 7.4, $10 \mathrm{mM} \mathrm{MgCl} 2$ with $6 \mu \mathrm{M}\left[1-{ }^{14} \mathrm{C}\right]-\alpha$-naphthol and $1 \mathrm{mM}$ UDPGA (Sigma-Aldrich, Madrid, Spain) (final volume $250 \mu \mathrm{l}$ ) at $37^{\circ} \mathrm{C}$ for $1 \mathrm{~h}$. Reactions were stopped by addition of $250 \mu \mathrm{l}$ of acetonitrile and samples were centrifuged for $5 \mathrm{~min}$ at 10,000g. Supernatant 
samples $(100 \mu \mathrm{l})$ were analyzed by HPLC coupled to on-line radioactivity detection according to Thibaut et al. [20]. $\alpha$-Naphthol and $\alpha$-naphthol-glucuronide were quantified by integrating the area under the radioactive peak.

\subsection{Transfection.}

Cells were plated in $35-\mathrm{mm}$ plates the day before transfection. aODNs were mixed with $\mathrm{N}$ [1-(2,3-dioleoyloxy)propyl]-N,N,N-trimethylammonium methylsulfate (DOTAP, Roche, Mannheim, Germany) $10 \mu \mathrm{M}$ for 15 min at RT before lipofecting the cells. siRNAs were mixed with $2 \mu \mathrm{l}$ of Metafectene (Biontex, Martinsried/Planegg, Germany), and plasmids with $3 \mu$ of Fugene (Roche, Mannheim, Germany) in medium without serum nor antibiotics for 15 min at RT. aODNs sequences were (Sigma-Aldrich, Madrid, Spain): UGT1A1 5'GCcCTgggaCtCCaCagCCAT-3'; UGT1A3-5 5'- GGgaaCCTggagTcCTgTggCCAT -3'; and aCDK4 5'-ctcAtAtcGAGAGGtAGccaT-3' (the capital letters contained phosphorothioate linkages). siRNAs sequences were (Thermo, Barcelona, Spain): UGT1A6-A anti strand 5'CAAGGAAGUUGGCCACUCGTT -3'; UGT1A6-B anti strand 5'AAAUGAUUGGUAACGGUUCTT -3'; Luciferase sense strand 5'UAAGGCUAUGAAGAGAUACTT-3; DHFR2-MIS anti strand 5'AAUGAGGAGGUUGUGGAGGTT-3'. Plasmid pCMV-UGT1A6-1 (Type 1) was purchased from Origene (Rockville, Maryland).

\subsection{MTT assay.}

Cells $(30,000)$ were plated in $35-\mathrm{mm}$ plates in $1 \mathrm{ml}$ of -GHT medium. Methotrexate was added 48 hours after transfection. However, it was supplied at the time of plating when performing experiments using SN-38 and Tamoxifen that were added 24 hours latter. Seven days after plated, $500 \mu \mathrm{g}$ of MTT (Sigma-Aldrich, Madrid, Spain) and $5.6 \mathrm{mg}$ of succinate 
(Sigma-Aldrich, Madrid, Spain) were added and allowed to react for 3 hours at $37^{\circ} \mathrm{C}$ before the addition of the solubilisation reagent ( $0.57 \%$ acetic acid and $10 \%$ SDS in DMSO). Cell viability was measured at $570 \mathrm{~nm}$ in a WPA S2100 Diode Array Spectrophotometer.

\subsection{Plasmid construction.}

Two plasmids of different insert length containing the UGT1A6 human promoter were constructed: pUGT1A6-Prom1000 and pUGT1A6-Prom2000. The two promoter inserts of 1071 and $2001 \mathrm{nt}$ in length respectively were generated by PCR amplification, using as template Human Genomic DNA (Promega Biotech Ibérica, Madrid, Spain), and the highfidelity DNA polymerase Phusion (Finnzymes, Espoo, Finland). UGT1A6 Prom-1000-Fw 5'cacttgctagcTGGACACAGCTCCTGAAACC-3'; UGT1A6 Prom-1000-Rv 5'gcacaaagcttTCCAAATCACAGGGCTCCTA-3'; UGT1A6 Prom-2000-Fw 5'cacttgctagcTCAGCTCCTTCCTCCAACTC-3'; UGT1A6 Prom-2000-Rv 5'gcacaaagcttAACCACTGCTTTTCACAGGTC-3'; NheI site in Fw primers and HindIII site in Rv are underlined. The fragments were cloned in a pGl4-basic (Promega Biotech Ibérica, Madrid, Spain) vector at the HindIII and NheI sites. The plasmid constructions were sequenced by Macrogen (Korea) using the primers pGL4-Prom-Fw 5'-

\section{AAATAGGCTGTCCCCAGTGC-3'; pGL4-Prom-Rv 5'-}

CGTCTTCGAGTGGGTAGAATG-3' and UGT1A6 Pr-2000 seq 5'-

AGGCTTCTTCTCCCTTCCTG-3'. No difference was observed when comparing the sequences with that reported in Genbank (Accession number $\underline{\text { NC_000002.11). The Match }}{ }^{\mathrm{TM}}$ software, using TRANSFAC 6.0 database was used to determine the putative transcription factor binding sites present in UGT1A6 promoter. There are putative ARNT and AhR/ARNT binding sites at -1230 and $-1504 \mathrm{nt}$, respectively, from the UGT1A6 type 2 translational start codon (ATG). 


\subsection{Luciferase assays.}

Cells were seeded into $35-\mathrm{mm}$ plates the day before transfection at a density of $2 \times 10^{5}$ cells/well in -GHT medium. Each well was co-transfected with $300 \mathrm{ng}$ of the appropriate plasmid and $10 \mathrm{ng}$ of Renilla plasmid (Promega Biotech Ibérica, Madrid, Spain) using FUGENETM6 (Roche, Mannheim, Germany). Luciferase activity was assayed $30 \mathrm{~h}$ after transfection. Cell extracts were prepared by lysing the cells with $200 \mu$ l of freshly diluted $1 x$ Reporter Lysis Buffer (Promega Biotech Ibérica, Madrid, Spain). The lysate was centrifuged at $13,000 \mathrm{~g}$ for $2 \mathrm{~min}$ to pellet the cell debris and the supernatants were transferred to a fresh tube. A $15-\mu 1$ aliquot of the extract was added to $15 \mu l$ of the luciferase assay substrate (Promega Biotech Ibérica, Madrid, Spain) and the luminescence of the samples was read immediately on a Gloomax 20/20 luminometer (Promega Biotech Ibérica, Madrid, Spain), in which the light production (relative light units, RLU) was measured for $5 \mathrm{~s}$. Then, $15 \mu \mathrm{l}$ of the 1X Renilla substrate in Stop \& Glo buffer was added, and light production was measured to normalize the results. A ratio between the luciferase and Renilla RLU was given.

\subsection{Binding analysis:}

\subsubsection{Preparation of AhR/ARNT and ARNT duplexes.}

The probes for the gel-shifts were generated by mixing $25 \mu \mathrm{g}$ of each single-stranded oligodeoxynucleotides in $150 \mathrm{mM} \mathrm{NaCl}$ : AhR-Fw 5'-aggaactcGCGTCccagcca-3'; AhR-Rv 5'-tggctggCACGCgagttcct-3'; ARNT-Fw 5'- ttctcacCACGTactggcta-3'; and ARNT-Rv 5'tagccagtACGTGgtgagaa-3' (the capital letters stand for the transcription factor binding site). After incubation at $90^{\circ} \mathrm{C}$ for 5 minutes, solutions were allowed to cool down slowly until reaching room temperature. Duplexes were purified in a non-denaturing $20 \%$ polyacrylamide gel and quantified by their absorbance at $260 \mathrm{~nm}$ at $25^{\circ} \mathrm{C}$. 


\subsubsection{Electrophoretic mobility shift assay (EMSA).}

Nuclear extracts were prepared from exponentially growing sensitive or resistant cells as described [21]. A double-stranded DNA probe corresponding to the AhR/ARNT or ARNT UGT1A6 promoter sites, was end-labelled with T4 polynucleotide Kinase (New England Biolabs, Ipswich, Massachusetts) and $\left[\gamma_{-}{ }^{32} \mathrm{P}\right] \mathrm{ATP}(3000 \mathrm{Ci} / \mathrm{mmol}$, Perkin Elmer, Madrid, Spain), and used in the gel-shift assays. DNA binding assays were performed as described [22] and were analyzed on a Storm 840 Phosphorimager (Molecular Dynamics). Salmon Testes DNA (Sigma-Aldrich, Madrid, Spain) was used as a non-specific competitor in a 1:8 non-specific/specific ratio. In the supershift experiments, $1 \mu \mathrm{g}$ of rabbit polyclonal antibody AhR or ARNT (both from Santa Cruz, Heidelberg, Germany) was added to the reaction mixture. Both antibodies were added at the same time as the probe and AhR was incubated $\mathrm{OVN}$ at $4^{\circ} \mathrm{C}$ and $\mathrm{ARNT}$ was incubated for $30 \mathrm{~min}$ at room temperature.

\subsection{Statistical analysis.}

Data are presented as the mean \pm SEM. Statistical analysis was performed using Student's t-test using InStat software for Mac OS X. Results were considered significant if $p<0.05(*), p<$ $0.01(* *)$, or $p<0.005(* * *)$. 


\section{RESULTS}

\subsection{Differential gene expression between cells sensitive and resistant to MTX.}

Microarray analyses between sensitive and resistant cells to $10^{-6} \mathrm{M}$ methotrexate were performed using MCF7 and MDA-MB-468 breast cancer cell lines. A list of the 2-fold differentially expressed genes that were statistically significant and passed the Benjamini and Hochberg-FDR was obtained for each cell line. Both cell lines overexpressed UGT1A, a 24fold increase in MCF7-R and a 28-fold increase in MDA-MB-R. Validation of UGT1A family overexpression was carried out by RT-Real Time PCR (Fig.1). Among the members of the UGT1A family a different expression pattern was observed. MCF7-R (Fig.1A) and MDAMB-R (Fig.1B) shared UGT1A1, UGT1A3, UGT1A4, UGT1A5 and UGT1A6 overexpression. UGT1A6 was the family member that showed the greatest increase between resistant and sensitive cells in both cell lines, 15-fold increase in MCF7-R cells and 46-fold in MDA-MB-R. UGT1A6 is composed of two isoforms that differ on the 5'UTR and the transcription start site, Type 1 and Type 2. MCF7-R cells showed a noticeable increase in Type 1 UGT1A6, a 12-fold increase, whereas MDA-MB-R had an increase in both Type 1 and Type 2 UGT1A6, 55- and 40-fold increase, respectively (Fig.2A MCF7 and 2B MDA$\mathrm{MB})$.

\subsection{Copy number.}

We explored whether or not UGT1A6 overexpression was due to gene amplification by Real Time-PCR. No changes in copy number were found between sensitive and resistant cells in both cell lines for either UGT1A6 or UGT1A4, another UGT family member with a noticeable overexpression (Fig.2C MCF7 and 2D MDA-MB), suggesting an increase in the transcription rate. 


\subsection{UGT1A activity.}

We studied whether the noticeable increase in UGT1A6 mRNA levels in MTX resistant cells was followed by a rise in UGT1A6 activity. The measurement of UGT1A activity, determined by $\left[1-{ }^{14} \mathrm{C}\right]-\alpha$-naphthol-glucuronide formation, showed a clear increase in MCF7R and MDA-MB-R cells, of 2-fold and 9-fold, respectively (Fig.2E).

\subsection{Inhibition of UGT1A6 expression and MTX sensitization.}

To study the role of UGT1A6-1 (Type 1) in MTX resistance in breast cancer cells, inhibition of its expression was carried out by siRNAs. Two different siRNAs against UGT1A6-1 were designed to ensure the specificity of the results. No increases in sensitivity to MTX were observed in MCF7-S or R and MDA-MB-S or R upon UGT1A6-1 siRNA transfection (data not shown). Then, we studied the influence of the other overexpressed UGTs in MTX resistance. As with UGT1A6, no differences in sensitivity to MTX were observed when inhibiting UGT1A1 or UGT1A3-5 in MCF7-S or R and MDA-MB-S or R (data not shown). The functionality of the inhibiting molecules against UGT1A6-1 and UGT1A1 or UGT1A3-5 was confirmed by the decrease in the mRNA levels of the specific UGT1A targets (data not shown). The lack of an increased sensitivity to MTX after down regulation of the overexpressed UGTs found in resistant cells suggests a redundant action among the different UGT isoforms, as a siRNA targeting the whole UGT1A family sensitized cells to MTX [23].

\subsection{UGT1A6-1 overexpression and MTX resistance.}

The influence of UGT1A6-1 overexpression in MTX resistance was studied in sensitive breast cancer cells by the transfection of a plasmid containing the UGT1A6-1 gene. Sensitive breast cancer cells incubated with $3 \cdot 10^{-8} \mathrm{M}$ MTX plus $1 \mu \mathrm{g}$ of pCMV-UGT1A6-1 displayed a 
significant increase in cell survival referred to cells treated with MTX alone, of $20 \%$ in MCF7 (Fig.3A) and 48\% in MDA-MB cells (Fig.3B). This rise in cell survival was specific of UGT1A6-1 as the empty vector did not cause any effect. The increase in UGT1A6-1 mRNA levels upon plasmid transfection was confirmed by RT-Real Time PCR (data not shown).

\subsection{Effect of MTX on UGT1A mRNA levels.}

We studied whether MTX was able to induce UGT1A gene expression. MCF7-S and MDAMB-S cells were incubated for 24 hours with $3 \cdot 10^{-8} \mathrm{M}$ MTX, and then UGT1A mRNA levels were analysed by RT-Real Time-PCR. MCF7-S (Fig.4A) and MDA-MB-S (Fig.4B) showed a similar pattern of induction of the UGT1A family. In both cases, when measuring the mRNA levels of the UGT1A family as a pool (1A*), an increase was observed, of 2-fold in MCF7-S MTX treated cells and 3.8-fold in MDA-MB-S. However, when determining the mRNA levels of each specific member of the UGT1A family upon MTX incubation, we observed two patterns of expression, one for the UGT1A1-6 cluster for which induction was the predominant response, and another for the UGT1A7-10 cluster for which inhibition was prevalent. Both cell lines had in common the increase in the expression of UGT1A1, UGT1A4 and UGT1A6, and the decrease in the expression of UGT1A8, UGT1A9 and UGT1A10. In MCF7-S and MDA-MB-S cells treated with MTX, UGT1A6 was the family member that presented the highest rise in expression, 2.4-fold for MCF7-S and 5.7-fold for MDA-MB-S.

\subsection{UGT1A activity upon MTX incubation.}

We analysed whether the induction that MTX exerted on UGT1A6 mRNA levels was translated into a higher glucuronidation activity. Since MDA-MB-S cells showed a greater response to MTX induction, they were selected for the enzymatic determination. Therefore, 
these cells were incubated in - GHT medium for different periods of time with $3 \cdot 10^{-8} \mathrm{M}$ MTX.

As shown in figure $4 \mathrm{C}$, a noticeable increase in the glucuronidation levels of $\left[1-{ }^{14} \mathrm{C}\right]-\alpha-$ naphthol- was observed at 48 hours, despite an initial decrease at $24 \mathrm{~h}$.

\subsection{Effect of MTX on UGT1A6 transcriptional activity.}

MTX induced UGT1A6 expression, so we proceeded to study if that induction was the result of a transcriptional activation. Two different luciferase reporter plasmids containing $1071 \mathrm{bp}$ or 2001 bp of the UGT1A6 promoter were constructed. Cells were transfected with these plasmids and the Renilla plasmid to normalize the results. In both cell lines, MTX caused an increase in promoter activity but only from the 2001 bp fragment (Fig.5A MCF7 and 5B MDA-MB). This increase in transcription activity was observed either in sensitive or resistant cells. The luciferase activity from the empty vector (pGL4) remained unchanged when incubated with MTX (data not shown).

\subsection{Transcription factors binding to the UGT1A6 promoter.}

The luciferase assays indicated that the region responsible for MTX induction was located between the -1071 to $-2001 \mathrm{bp}$ of the UGT1A6 promoter region. Computational analysis using the Transfac database revealed the presence of binding sites for two transcription factors that could be involved in MTX induction, AhR/ARNT and ARNT, which are related to xenobiotics metabolism and oxidative stress. Nuclear extracts from MCF7 and MDA-MB sensitive and resistant to MTX were incubated with two radiolabelled probes derived from the UGT1A6 promoter containing the binding sites for either AhR/ARNT or ARNT. A similar behaviour was observed in both breast cancer cell lines with both probes (Fig.6A and 7A). Sensitive cells showed three retardation bands using the AhR/ARNT as well as ARNT probes. When these cells were treated with $3 \cdot 10^{-8} \mathrm{M}$ MTX for 24 hours, only the band with the lowest 
mobility could be observed in the gel shift with a intensity higher than in untreated cells. Resistant cells showed this same retardation pattern of a unique shifted band that did not change when these cells were depleted of MTX for 24 hours. Supershift assays were performed to assess the specificity and identity of the retardation bands. When MCF7-S nuclear extracts were incubated with an AhR antibody, the three retardation bands disappeared, indicating that the antibody blocked the formation of the AhR/ARNT-probe complex (Fig.6B). MCF7-S nuclear extracts incubated with the ARNT antibody produced a super-shifted band due to the reduced mobility of the Ab-ARNT-probe complex, as well as the disappearance of the upper band of the three bands present in the gel-shift (Fig.7B).

\subsection{Influence of MTX in UGT1A metabolism of other drugs.}

Tamoxifen and the active metabolite of irinotecan, $\mathrm{SN}-38$, are two drugs metabolized by UGT1A. The IC50 for SN-38 was $0.75 \mathrm{nM}$ in MDA-MB cells and $0.75 \mu \mathrm{M}$ in MCF7 cells, the IC50 for TMX was $0.35 \mu \mathrm{M}$ in MCF7 cells, and the IC50 for MTX was $6 \cdot 10^{-8} \mathrm{M}$ in both cell lines. When MDA-MB-S or MCF7-S cells were incubated with increasing concentrations of SN-38, a noticeable cell death was observed (Fig.8A and 9A). However, cells incubated with SN-38 together with $2 \cdot 10^{-8} \mathrm{M}$ MTX, showed a cell survival recovery of $22 \%$ with 0.01 $\mu \mathrm{M}$ SN-38 in MDA-MB-S (Fig.8A), reaching a $43 \%$ at $0.025 \mu \mathrm{M}$ SN-38 in MCF7-S (Fig.9A), probably due to SN-38 increased glucuronidation upon MTX incubation. MDAMB-R and MCF7-R cells did not present significant changes in cell survival, when incubated with SN-38 and MTX $1 \cdot 10^{-6} \mathrm{M}$ (Fig.8B and 9B). This effect could be explained by the fact that methotrexate resistant cells show already high levels of UGT1A6 regardless of the presence of MTX. Tamoxifen was assayed in MCF7 cells only as the mechanism of action of this drug needs ER+ cells (Fig.10). Similar to SN-38 behaviour, sensitive cells incubated with tamoxifen together with MTX had a higher cell survival than those incubated with tamoxifen 
1

alone, reaching a $36 \%$ of cell survival recovery when incubated with $1 \mu \mathrm{M}$ tamoxifen

(Fig.10A). Resistant cells did not show significant changes in cell survival due to the presence or absence of MTX (Fig.10B). The vehicle of both drugs, DMSO, did not cause significant changes in cell survival. 


\section{DISCUSSION}

Drug resistance constitutes a drawback of cancer treatment. Microarray analysis of two different breast cancer cell lines resistant to methotrexate, MCF7-R and MDA-MB-R, pointed out UGT1A, as the only gene family in common between them. Additionally, it is worth noting that ABCG2 MTX transporter was about 10-fold overexpressed in MCF7-R cells, although no significant changes in ABCG2 expression were observed in MDA-MB-R.

Among the different members of UGT1A family, the cluster formed by UGT1A1 through 6, and specifically UGT1A6, showed to be the main responsible for the rise of UGT1A expression in breast cancer resistant cells. UGT1A6 is a major UGT in humans that mediates glucuronidation [24] and is responsible for the metabolism of drugs, such as acetaminophen [25] and valproate [26]; carcinogens, such as benzo(a)pyrene; and endogenous substrates, including serotonin [27] and 5-hydroxytryptophol [28]. Glucuronidation is one of the main phase II clearance mechanisms for drugs, dietary natural and chemical products as well as environmental substances in humans. Glucuronidation increases water solubility of compounds, enabling their elimination of the body via urine or bile acids.

UGT1A family could somehow contribute to MTX metabolism to a certain degree, as it shares a phenolic structure common to other UGT1A substrates. This effect could be hypothesized from the increased survival observed in sensitive cells treated with MTX when UGT1A6 was overexpressed. However, no increase in sensitivity to MTX was observed when a siRNA against UGT1A6 was used. Different aODNs towards the remaining members of the UGT1A1-6 cluster were also tested, to evaluate whether another family member was responsible for MTX metabolism, but increase in sensitivity was neither observed. The lack of sensitization towards MTX when UGT1A6 was downregulated could be explained by the 
redundant action of the different UGTs isoforms. In previous studies, when MTX-treated cells were transfected with a siRNA targeting the whole UGT1A family, an increase in cell sensitivity was observed, supporting the hypothesis of UGT1A redundancy [23]. On the other hand, it is difficult to discriminate the contribution of a single UGT isoform in the metabolism of an UGT substrate. No isoform-specific substrates, UGT isoform-specific chemical inhibitors or inhibitory antibodies are available [29].

UGT1A overexpression in both breast cancer cell lines resistant to MTX was not due to gene amplification, but to an increase in UGT1A transcription that led to an increased UGT1A activity. UGT1A family is characterised by its induction by a wide range of compounds. Among the chemicals that induce UGT1A6 expression we can find: flavonoids, sulforaphane [30], LPS [31], 3-methylcholanthrene (3-MC) [32, 33], benzo[a]pyrene (B[a]P), dioxin [34], b-naphthoflavone (BNF) [35], oltipraz [36-38], and rifampicin [39]. MTX could be an UGT1A6 inducer according to our results of increased mRNA levels, luciferase activity and UGT1A enzymatic activity.

The different transcription factors involved in UGT1A induction include activator protein 1 (AP-1) [32], constitutive active receptor (CAR) [40], pregnane X receptor (PXR) [41], peroxisome proliferator-activated receptor (PPAR) [42], antioxidant response element (ARE) through Nrf2 [36, 43] and aryl hydrocarbon receptor (AhR) [44]. AhR was described to provoke moderate UGT1A6 induction in humans and rodents [14, 45-48]. This transcription factor is located in the cytoplasm and upon activation by ligand binding, it enters the nucleus and interacts with the AhR nuclear translocator protein (ARNT), forming the AhR/ARNT heterodimer that binds to a specific DNA sequence called xenobiotic response element (XRE, 5'-GCGTG-3') [49]. AhR/ARNT binding to XRE activates the expression of a battery of genes involved in drug and hormone metabolism, e.g., CYP1A1, CYP1B1, CYP1A2, 
ALDH3, GSTA2, NAD(P)H:quinone reductase and UGT1A6 [50, 51]. TCDD (dioxin) is one of the compounds that induce UGT1A6 via AhR binding to the XRE as it has been observed in primary hepatocyte cultures and in colon carcinoma Caco-2 cells [14]. Some AhR agonists cause coordinate induction of both phase-I CYPs and UGTs to attenuate the generation of mutagenic benzo[a]pyrene metabolites, facilitating detoxification of the carcinogen [52]. In addition, UGTs may be responsible for homeostatic control of AhR ligands, such as bilirubin [52]. AhR can also induce UGT1A6 expression through Nrf2 binding to the ARE element present in the UGT1A6 promoter [43], however no induction in response to MTX was observed in the luciferase assays for the first 1000 bp region, where the ARE site is located. Our luciferase and gel-shift results support the idea that MTX could be inducing UGT1A6 expression through AhR/ARNT heterodimers and ARNT itself. ARNT can also bind to other ligands like hypoxia-inducible factor 1 (HIF-1), which binds to a promoter sequence (5'CACGT-3') different from XRE. It has been shown that down-regulation of HIF-1 $\alpha$ by siRNA sensitizes MCF7 cells to MTX [53]. Furthermore, up-regulation of the hypoxia pathway by HIF not only confers an aggressive phenotype but also contributes to resistance to radiotherapy and chemotherapy [54]. The potential mechanisms for HIF-mediated drug resistance include the interference with the apoptotic pathway [55], the upregulation of the multidrug resistance transporter P-glycoprotein [56], and a poor drug delivery in functionally deficient vessels [54]. Thus, MTX could induce UGT1A6 through HIF, thus causing a phenotype more resistant to this drug. Another possibility would be that MTX, instead of directly activating AhR or ARNT, could bind to an ARNT inhibitor such as the short heterodimer partner (SHP) and SMRT, or activate ARNT through coactivators as CBP and ERAP140. SHP has been shown to inhibit a reporter activity induced by TCDD, an UGT1A6 substrate, in RL95-2 cells [51]. 
MTX induction of UGT1A6 may have important toxicological, pharmacological and physiological consequences, as it would decrease the bioavailability of many dietary constituents and drugs susceptible to glucuronidation, such as irinotecan and tamoxifen, which would become less active when administered simultaneously with MTX, as indicated by our results. UGTs have been reported to be responsible in part for the resistance to chemotherapeutic drugs such as daunorubicin [57] and mycophenolic acid [58], and as shown here they constitute an important element in MTX resistance in breast cancer cells. This type of cross-resistance between MTX and other chemotherapeutics has significant pharmacological repercussions and could represent a handicap to tumour treatment, since methotrexate is given in combination with other drugs such as tamoxifen to treat breast cancer. Additionally, any other drug susceptible to glucuronidation, such as paracetamol, given to a patient treated with MTX, would decrease its bioavailability and therapeutic effect.

In summary, we show that UGT1A6 is overexpressed in breast cancer cells resistant to methotrexate, and that this drug induces UGT1A6 mRNA and enzymatic activity, through a mechanism mediated by ARNT and AhR/ARNT. The pharmacological effect of this induction should be taken into account when combining methotrexate with other drugs susceptible to glucuronidation. 


\title{
ACKNOWLEDGEMENTS
}

\begin{abstract}
Work supported by grants SAF08-43 from "Plan Nacional de Investigación Científica" (Spain) and ISCIII-RETIC RD06/0020/0046. Our group holds the Quality mention from the "Generalitat de Catalunya" SGR09-118. M.C.A. is the recipient of a predoctoral fellowship from the "Generalitat de Catalunya" (FI).
\end{abstract}

\section{COMPETING INTERESTS}

The authors declare that they have no competing interests.

\section{FOOTNOTES}

${ }^{1}$ Present address: Centre de Genètica Cardiovascular, Universitat de Girona-IdIBGi, Parc

Científic i Tecnològic, Pic de Peguera 11-15,17003 Girona, Spain 


\section{REFERENCES}

[1] Mayo C. [http://wwwmayocliniccom] 05/15/2010

[2] Chu E, Grem JL, Johnston PG, Allegra CJ. New concepts for the development and use of antifolates. Stem Cells 1996;14:41-6.

[3] Gorlick R, Goker E, Trippett T, Steinherz P, Elisseyeff Y, Mazumdar M, et al. Defective transport is a common mechanism of acquired methotrexate resistance in acute lymphocytic leukemia and is associated with decreased reduced folate carrier expression. Blood 1997;89:1013-8.

[4] Blakley RL, Cocco L. Dismutation of dihydrofolate by dihydrofolate reductase. Biochemistry 1984;23:2377-83.

[5] Nagar S, Remmel RP. Uridine diphosphoglucuronosyltransferase pharmacogenetics and cancer. Oncogene 2006;25:1659-72.

[6] Burchell B. Genetic variation of human UDP-glucuronosyltransferase: implications in disease and drug glucuronidation. Am J Pharmacogenomics 2003;3:37-52.

[7] Mackenzie PI, Owens IS, Burchell B, Bock KW, Bairoch A, Belanger A, et al. The UDP glycosyltransferase gene superfamily: recommended nomenclature update based on evolutionary divergence. Pharmacogenetics 1997;7:255-69.

[8] Gong QH, Cho JW, Huang T, Potter C, Gholami N, Basu NK, et al. Thirteen UDPglucuronosyltransferase genes are encoded at the human UGT1 gene complex locus. Pharmacogenetics 2001;11:357-68.

[9] Clarke DJ, Cassidy AJ, See CG, Povey S, Burchell B. Cloning of the human UGT1 gene complex in yeast artificial chromosomes: novel aspects of gene structure and subchromosomal mapping to 2q37. Biochem Soc Trans 1997;25:S562.

[10] Nagar S, Blanchard RL. Pharmacogenetics of uridine diphosphoglucuronosyltransferase (UGT) 1A family members and its role in patient response to irinotecan. Drug Metab Rev 2006;38:393-409.

[11] Burchell B, Brierley CH, Rance D. Specificity of human UDPglucuronosyltransferases and xenobiotic glucuronidation. Life Sci 1995;57:1819-31.

[12] Ciotti M, Owens IS. Evidence for overlapping active sites for 17 alpha-ethynlestradiol and bilirubin in the human major bilirubin UDPglucuronosyltransferase. Biochemistry 1996;35:10119-24.

[13] Auyeung DJ, Kessler FK, Ritter JK. An alternative promoter contributes to tissue- and inducer-specific expression of the rat UDP-glucuronosyltransferase 1A6 gene. Toxicol Appl Pharmacol 2001;174:60-8.

[14] Munzel PA, Lehmkoster T, Bruck M, Ritter JK, Bock KW. Aryl hydrocarbon receptor-inducible or constitutive expression of human UDP glucuronosyltransferase UGT1A6. Arch Biochem Biophys 1998;350:72-8.

[15] Bock KW, Kohle C. UDP-glucuronosyltransferase 1A6: structural, functional, and regulatory aspects. Methods Enzymol 2005;400:57-75.

[16] Selga E, Noe V, Ciudad CJ. Transcriptional regulation of aldo-keto reductase 1C1 in HT29 human colon cancer cells resistant to methotrexate: role in the cell cycle and apoptosis. Biochem Pharmacol 2008;75:414-26.

[17] Chasin L. The dihydrofolate reductase locus. Molecular cell genetics 1985:449-88.

[18] Omnibus GE. http://wwwncbinlmnihgov/geo/. 05/15/2010

[19] Bradford MM. A rapid and sensitive method for the quantitation of microgram quantities of protein utilizing the principle of protein-dye binding. Anal Biochem 1976;72:248-54. 
[20] Thibaut R, Schnell S, Porte C. Assessment of metabolic capabilities of PLHC-1 and RTL-W1 fish liver cell lines. Cell Biol Toxicol 2009;25:611-22.

[21] Ciudad CJ, Morris AE, Jeng C, Chasin LA. Point mutational analysis of the hamster dihydrofolate reductase minimum promoter. J Biol Chem 1992;267:3650-6.

[22] Noe V, Alemany C, Nicolas M, Ciudad CJ. Sp1 involvement in the 4beta-phorbol 12myristate 13-acetate (TPA)-mediated increase in resistance to methotrexate in Chinese hamster ovary cells. Eur J Biochem 2001;268:3163-73.

[23] Selga E, Oleaga C, Ramirez S, de Almagro MC, Noe V, Ciudad CJ. Networking of differentially expressed genes in human cancer cells resistant to methotrexate. Genome Med 2009;1:83.

[24] Krishnaswamy S, Hao Q, Al-Rohaimi A, Hesse LM, von Moltke LL, Greenblatt DJ, et al. UDP glucuronosyltransferase (UGT) 1A6 pharmacogenetics: I. Identification of polymorphisms in the 5'-regulatory and exon 1 regions, and association with human liver UGT1A6 gene expression and glucuronidation. J Pharmacol Exp Ther 2005;313:1331-9.

[25] Court MH. Acetaminophen UDP-glucuronosyltransferase in ferrets: species and gender differences, and sequence analysis of ferret UGT1A6. J Vet Pharmacol Ther 2001;24:415-22.

[26] Ethell BT, Anderson GD, Burchell B. The effect of valproic acid on drug and steroid glucuronidation by expressed human UDP-glucuronosyltransferases. Biochem Pharmacol 2003;65:1441-9.

[27] Krishnaswamy S, Duan SX, Von Moltke LL, Greenblatt DJ, Court MH. Validation of serotonin (5-hydroxtryptamine) as an in vitro substrate probe for human UDPglucuronosyltransferase (UGT) 1A6. Drug Metab Dispos 2003;31:133-9.

[28] Krishnaswamy S, Hao Q, Von Moltke LL, Greenblatt DJ, Court MH. Evaluation of 5hydroxytryptophol and other endogenous serotonin (5-hydroxytryptamine) analogs as substrates for UDP-glucuronosyltransferase 1A6. Drug Metab Dispos 2004;32:862-9.

[29] Liu X, Tam VH, Hu M. Disposition of flavonoids via enteric recycling: determination of the UDP-glucuronosyltransferase isoforms responsible for the metabolism of flavonoids in intact Caco-2 TC7 cells using siRNA. Mol Pharm 2007;4:873-82.

[30] Wang M, Li YQ, Zhong N, Chen J, Xu XQ, Yuan MB. [Induction of uridine 5'diphosphate-glucuronosyltransferase gene expression by sulforaphane and its mechanism: experimental study in human colon cancel cells]. Zhonghua Yi Xue Za Zhi 2005;85:819-24.

[31] Heurtaux T, Benani A, Moulin D, Muller N, Netter P, Minn A. Induction of UGT1A6 isoform by inflammatory conditions in rat astrocytes. Neuropharmacology 2006;50:317-28.

[32] Emi Y, Ikushiro S, Iyanagi T. Drug-responsive and tissue-specific alternative expression of multiple first exons in rat UDP-glucuronosyltransferase family 1 (UGT1) gene complex. J Biochem 1995;117:392-9.

[33] Grams B, Harms A, Braun S, Strassburg CP, Manns MP, Obermayer-Straub P. Distribution and inducibility by 3 -methylcholanthrene of family 1 UDPglucuronosyltransferases in the rat gastrointestinal tract. Arch Biochem Biophys 2000;377:255-65.

[34] Munzel PA, Bookjans G, Mehner G, Lehmkoster T, Bock KW. Tissue-specific 2,3,7,8-tetrachlorodibenzo-p-dioxin-inducible expression of human UDPglucuronosyltransferase UGT1A6. Arch Biochem Biophys 1996;335:205-10.

[35] Yokota H, Ohgiya N, Ishihara G, Ohta K, Yuasa A. Purification and properties of UDP-glucuronyltransferase from kidney microsomes of beta-naphthoflavone-treated rat. J Biochem 1989;106:248-52. 
[36] Buetler TM, Gallagher EP, Wang C, Stahl DL, Hayes JD, Eaton DL. Induction of phase I and phase II drug-metabolizing enzyme mRNA, protein, and activity by BHA, ethoxyquin, and oltipraz. Toxicol Appl Pharmacol 1995;135:45-57.

[37] Grove AD, Kessler FK, Metz RP, Ritter JK. Identification of a rat oltipraz-inducible UDP-glucuronosyltransferase (UGT1A7) with activity towards benzo(a)pyrene-7,8dihydrodiol. J Biol Chem 1997;272:1621-7.

[38] Kessler FK, Ritter JK. Induction of a rat liver benzo[a]pyrene-trans-7,8-dihydrodiol glucuronidating activity by oltipraz and beta-naphthoflavone. Carcinogenesis 1997;18:107-14.

[39] van de Kerkhof EG, de Graaf IA, Ungell AL, Groothuis GM. Induction of metabolism and transport in human intestine: validation of precision-cut slices as a tool to study induction of drug metabolism in human intestine in vitro. Drug Metab Dispos 2008;36:604-13.

[40] Sugatani J, Kojima H, Ueda A, Kakizaki S, Yoshinari K, Gong QH, et al. The phenobarbital response enhancer module in the human bilirubin UDPglucuronosyltransferase UGT1A1 gene and regulation by the nuclear receptor CAR. Hepatology 2001;33:1232-8.

[41] Xie W, Yeuh MF, Radominska-Pandya A, Saini SP, Negishi Y, Bottroff BS, et al. Control of steroid, heme, and carcinogen metabolism by nuclear pregnane $\mathrm{X}$ receptor and constitutive androstane receptor. Proc Natl Acad Sci U S A 2003;100:4150-5.

[42] Barbier O, Villeneuve L, Bocher V, Fontaine C, Torra IP, Duhem C, et al. The UDPglucuronosyltransferase 1A9 enzyme is a peroxisome proliferator-activated receptor alpha and gamma target gene. J Biol Chem 2003;278:13975-83.

[43] Yeager RL, Reisman SA, Aleksunes LM, Klaassen CD. Introducing the "TCDDinducible AhR-Nrf2 gene battery". Toxicol Sci 2009;111:238-46.

[44] Emi Y, Ikushiro S, Iyanagi T. Xenobiotic responsive element-mediated transcriptional activation in the UDP-glucuronosyltransferase family 1 gene complex. J Biol Chem 1996;271:3952-8.

[45] Bock-Hennig BS, Kohle C, Nill K, Bock KW. Influence of t-butylhydroquinone and beta-naphthoflavone on formation and transport of 4-methylumbelliferone glucuronide in Caco-2/TC-7 cell monolayers. Biochem Pharmacol 2002;63:123-8.

[46] Auyeung DJ, Kessler FK, Ritter JK. Mechanism of rat UDP-glucuronosyltransferase 1A6 induction by oltipraz: evidence for a contribution of the Aryl hydrocarbon receptor pathway. Mol Pharmacol 2003;63:119-27.

[47] Jemnitz K, Veres Z, Vereczkey L. Coordinate regulation of UDPglucuronosyltransferase UGT1A6 induction by 3-methylcholanthrene and multidrug resistance protein MRP2 expression by dexamethasone in primary rat hepatocytes. Biochem Pharmacol 2002;63:2137-44.

[48] Soars MG, Petullo DM, Eckstein JA, Kasper SC, Wrighton SA. An assessment of udp-glucuronosyltransferase induction using primary human hepatocytes. Drug Metab Dispos 2004;32:140-8.

[49] Carver LA, LaPres JJ, Jain S, Dunham EE, Bradfield CA. Characterization of the Ah receptor-associated protein, ARA9. J Biol Chem 1998;273:33580-7.

[50] Kress S, Greenlee WF. Cell-specific regulation of human CYP1A1 and CYP1B1 genes. Cancer Res 1997;57:1264-9.

[51] Klinge CM, Jernigan SC, Risinger KE, Lee JE, Tyulmenkov VV, Falkner KC, et al. Short heterodimer partner (SHP) orphan nuclear receptor inhibits the transcriptional activity of aryl hydrocarbon receptor (AHR)/AHR nuclear translocator (ARNT). Arch Biochem Biophys 2001;390:64-70. 
[52] Bock KW, Bock-Hennig BS. UDP-glucuronosyltransferases (UGTs): from purification of Ah-receptor-inducible UGT1A6 to coordinate regulation of subsets of CYPs, UGTs, and ABC transporters by nuclear receptors. Drug Metab Rev 2009.

[53] Li J, Shi M, Cao Y, Yuan W, Pang T, Li B, et al. Knockdown of hypoxia-inducible factor-1alpha in breast carcinoma MCF-7 cells results in reduced tumor growth and increased sensitivity to methotrexate. Biochem Biophys Res Commun 2006;342:134151.

[54] Generali D, Berruti A, Brizzi MP, Campo L, Bonardi S, Wigfield S, et al. Hypoxiainducible factor-1alpha expression predicts a poor response to primary chemoendocrine therapy and disease-free survival in primary human breast cancer. Clin Cancer Res 2006; 12:4562-8.

[55] Erler JT, Cawthorne CJ, Williams KJ, Koritzinsky M, Wouters BG, Wilson C, et al. Hypoxia-mediated down-regulation of Bid and Bax in tumors occurs via hypoxiainducible factor 1-dependent and -independent mechanisms and contributes to drug resistance. Mol Cell Biol 2004;24:2875-89.

[56] Wartenberg M, Ling FC, Muschen M, Klein F, Acker H, Gassmann M, et al. Regulation of the multidrug resistance transporter P-glycoprotein in multicellular tumor spheroids by hypoxia-inducible factor (HIF-1) and reactive oxygen species. FASEB J 2003;17:503-5.

[57] Gessner T, Vaughan LA, Beehler BC, Bartels CJ, Baker RM. Elevated pentose cycle and glucuronyltransferase in daunorubicin-resistant P388 cells. Cancer Res 1990;50:3921-7.

[58] Franklin TJ, Jacobs V, Jones G, Ple P, Bruneau P. Glucuronidation associated with intrinsic resistance to mycophenolic acid in human colorectal carcinoma cells. Cancer Res 1996;56:984-7. 


\section{FIGURE LEGENDS}

Figure 1. UGT1A mRNA levels. Basal mRNA levels of the different members of the UGT1A family in sensitive or $10^{-6} \mathrm{M}$ MTX resistant cells. Prior to RT-Real Time PCR, mRNA was submitted to DNAse treatment. Expression data of UGT1A family members are referred to UGT1A3 mRNA levels of sensitive cells, whose value was taken as 1. A) MCF7-S and MCF7-R. B) MDA-MB-S and MDA-MB-R. Data represent the mean \pm SEM of at least four experiments. $* \mathrm{p}<0.05, * * \mathrm{p}<0.01$, or $* * * \mathrm{p}<0.005$.

\section{Figure 2. Type 1 and type 2 UGT1A6 mRNA levels, copy number and UGT activity.} Basal UGT1A6 mRNA levels of sensitive and $10^{-6} \mathrm{M}$ MTX resistant cells; A) MCF7 and B) MDA-MB. Prior to RT-Real Time PCR, mRNA was submitted to DNAse treatment. Data are referred to sensitive cells and represent the mean \pm SEM of three experiments. C) and D) UGT1A6 and UGT1A4 copy number of sensitive and MTX resistant cells. C) MCF7 and D) MDA-MB. Data are referred to sensitive cells and represent the mean \pm SEM of five experiments. E) UGT1A activity. The S9 fraction of MDA-MB and MCF7 cells, either sensitive or resistant, was incubated with $\left[1-{ }^{14} \mathrm{C}\right]-\alpha$-naphthol and UGT1A activity was measured by HPLC. Data represent the mean \pm SEM of three experiments. * $\mathrm{p}<0.05, * * \mathrm{p}<$ 0.01, or $* * * \mathrm{p}<0.005$

\section{Figure 3. Methotrexate cytotoxicity upon UGT1A6-1 plasmid transfection. 30,000}

sensitive cells were incubated in -GHT medium. The following day, cells were transfected with the appropriated plasmid using Fugene. 48 hours after transfection, cells were treated with $3 \cdot 10^{-8} \mathrm{M}$ MTX. The empty vector $\mathrm{pCMV}$ was used as a negative control. Data represent the fold change referred to cells not treated with MTX. MTT assays were performed a week 
after transfection. A) MCF7-S cells. B) MDA-MB-S cells. Data represent the mean \pm SEM of at least five experiments. $* \mathrm{p}<0.05, * * \mathrm{p}<0.01$, or $* * * \mathrm{p}<0.005$.

Figure 4. UGT1A mRNA and activity after MTX incubation. A) and B) 500,000 sensitive cells were incubated for 24 hours with $3 \cdot 10^{-8} \mathrm{M}$ MTX. Total mRNA was obtained and submitted to DNAse treatment prior to RT-Real Time PCR. Data represent the fold change referred to cells non treated with MTX. A) MCF7-S cells. B) MDA-MB-S cells. Data represent the mean \pm SEM of at least three experiments. C) UGT1A activity. MDA-MB sensitive cells were incubated for 24 and 48 hours with $3 \cdot 10^{-8} \mathrm{M}$ MTX. The microsomal fraction was obtained and UGT1A activity was analysed through $\left[1-{ }^{14} \mathrm{C}\right]-\alpha$-naphthol glucuronidation. Data represent the mean \pm SEM of two experiments. $* \mathrm{p}<0.05, * * \mathrm{p}<0.01$, or $* * * \mathrm{p}<0.005$

Figure 5. Analysis of UGT1A6 promoter by luciferase activity. 200,000 cells were incubated in -GHT medium. The following day, cells were transfected with the appropriated plasmid using Fugene and incubated either in the presence or in the absence of MTX. Thirty hours latter dual luciferase assays were performed. The control was the empty vector, pGl4. Renilla was used to normalise the data. A) MCF7 cells and B) MDA-MB cells. Data represent the mean \pm SEM of at least three experiments. $* p<0.05$.

Figure 6. Binding of AhR to UGT1A6 promoter. Cells were incubated with or without MTX for 24 hours prior to nuclear extracts harvest. Nuclear extracts were incubated with a radiolabelled probe corresponding to UGT1A6 AhR/ARNT promoter sequence. A) MCF7 sensitive and resistant and MDA-MB sensitive and resistant. B) AhR supershift. Incubation of 
MCF7-S nuclear extracts with AhR antibody. Shifted and supershifted bands are indicated by arrows.

Figure 7. Binding of ARNT to UGT1A6 promoter. Cells were incubated with or without MTX for 24 hours prior to nuclear extracts preparation. Nuclear extracts were incubated with a radiolabelled probe corresponding to UGT1A6 ARNT promoter sequence. A) MCF7 sensitive and resistant and MDA-MB sensitive and resistant. B) ARNT supershift. Incubation of MCF7-S nuclear extracts with ARNT antibody. Shifted and supershifted bands are indicated by arrows.

Figure 8. $\mathrm{SN}-38$ cytotoxicity in the presence of MTX in MDA-MB cells. 30,000 cells were incubated in -GHT medium either in the absence or in the presence of MTX. The following day, cells were incubated with the appropriated SN-38 concentration. The vehicle of SN-38, DMSO was tested alone at the concentrations used. MTT assays were performed a week after adding MTX. A) MDA-MB-S cells and B) MBA-MB-R cells. Data represent the mean \pm SEM of four experiments. $* \mathrm{p}<0.05, * * \mathrm{p}<0.01$, or $* * * \mathrm{p}<0.005$

Figure 9. SN-38 cytotoxicity in the presence of MTX in MCF7 cells. A) MCF7-S cells and B) MCF7-R cells. Data represent the mean \pm SEM of four experiments. Other conditions as in Figure 8.

Figure 10. Tamoxifen cytotoxicity in the presence of MTX in MCF7 cells. 30,000 cells were incubated in-GHT medium in the absence or in the presence of MTX. The following day, cells were incubated with the appropriated tamoxifen concentration. The vehicle of tamoxifen, DMSO was tested alone at the concentrations used. A) MCF7-S cells and B) 
1

2

3

4

5

6

7

8

9

10

11

12

13

14

15

16

17

18

19

20

21

22

23

24

25

26

27

28

29

30

31

32

33

34

35

36

37

38

39

40

41

42

43

44

45

46

47

48

49

50

51

52

53

54

55

56

57

58

59

60

61

62

63

64

65

MCF7-R cells. Data represent the mean \pm SEM of four experiments. Other conditions as in Figure 8. 
Additional table 1. Sequences of the primers used in the study

\begin{tabular}{|c|c|c|}
\hline Primers & For & Rev \\
\hline UGT1A Ex3-4 & TAAGTGGCTACCCCAAAACG & CTCCAGCTCCCTTAGTCTCC \\
\hline UGT1A1 & CATCAGAGACGGAGCATTTTACAC & GTCCGTCAGCATGACATCAAAG \\
\hline UGT1A3 & TAACAGACCCCGTTAACCTCTGC & AAAAGCATGGCAAATGTAGGACAG \\
\hline UGT1A4 & CTTCTGCTGAGATGGCCAGAG & CTGGGTCCATGGAACAGCATAG \\
\hline UGT1A5 & GGGAAGGTGCTGGTGGTG & TGTTTCAAAGAACGATTGAGTGTG \\
\hline UGT1A6 & GGCCTACCATCTGTGTACCTCTTC & ATCCACATCTCTCTTGAGGACAGC \\
\hline UGT1A7 & CTTTGCCAAGGCAGGGAAG & AGAAAATGCACTTCGCAATGG \\
\hline UGT1A8 & CCTATGTGTTTCTCTGCTGCTGAC & TCCAGATCCTCCAGAGTGTATGAG \\
\hline UGT1A9 & AGCCCCCTTCCTCTATGTGT & TGGCATGACTACAACCACCT \\
\hline UGT1A10 & TAQMAN PROBE Hs02516990_s1 & \\
\hline UGT1A6-1 UTR & GCCGTATGACCAAGAAGAGC & GGCTGGGTCTGTGAAAAGAG \\
\hline UGT1A6-2 UTR & GAAGCTCAGGAGAGGAGTC & GAAGTATAAGTCTAGCCAGTACG \\
\hline APRT & TAQMAN PROBE Hs00356991_m1 & \\
\hline APRT-H-DNA & CGGGAACCCTCGTCTTTCGCCCCC & GCCTCGGGGGCTCAATCTCACAAC \\
\hline APRT-H & GCAGCTGGTTGAGCAGCGGAT & AGAGTGGGGCCTGGCAGCTTC \\
\hline
\end{tabular}




\section{Figure}

Click here to download high resolution image

\section{A}

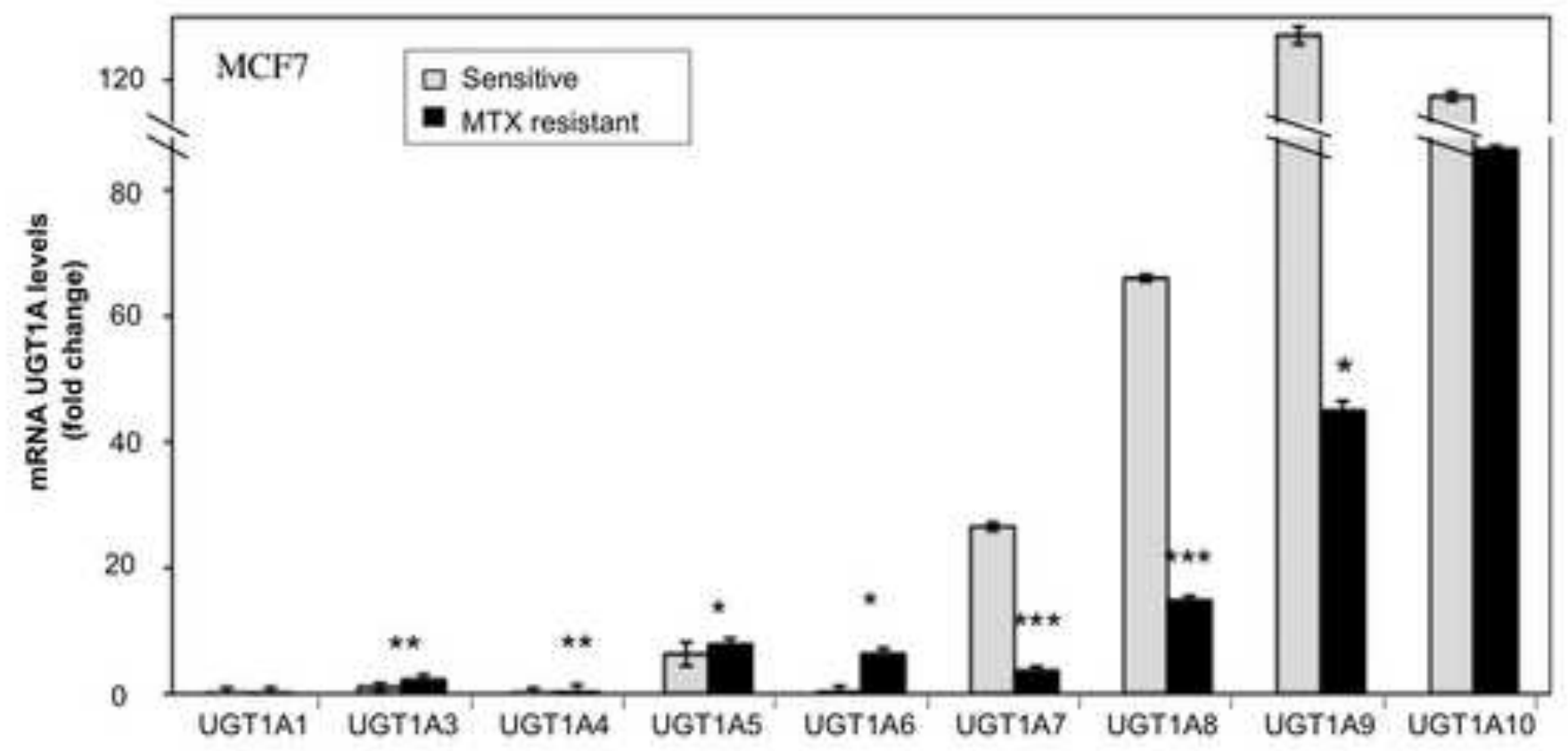

\section{B}

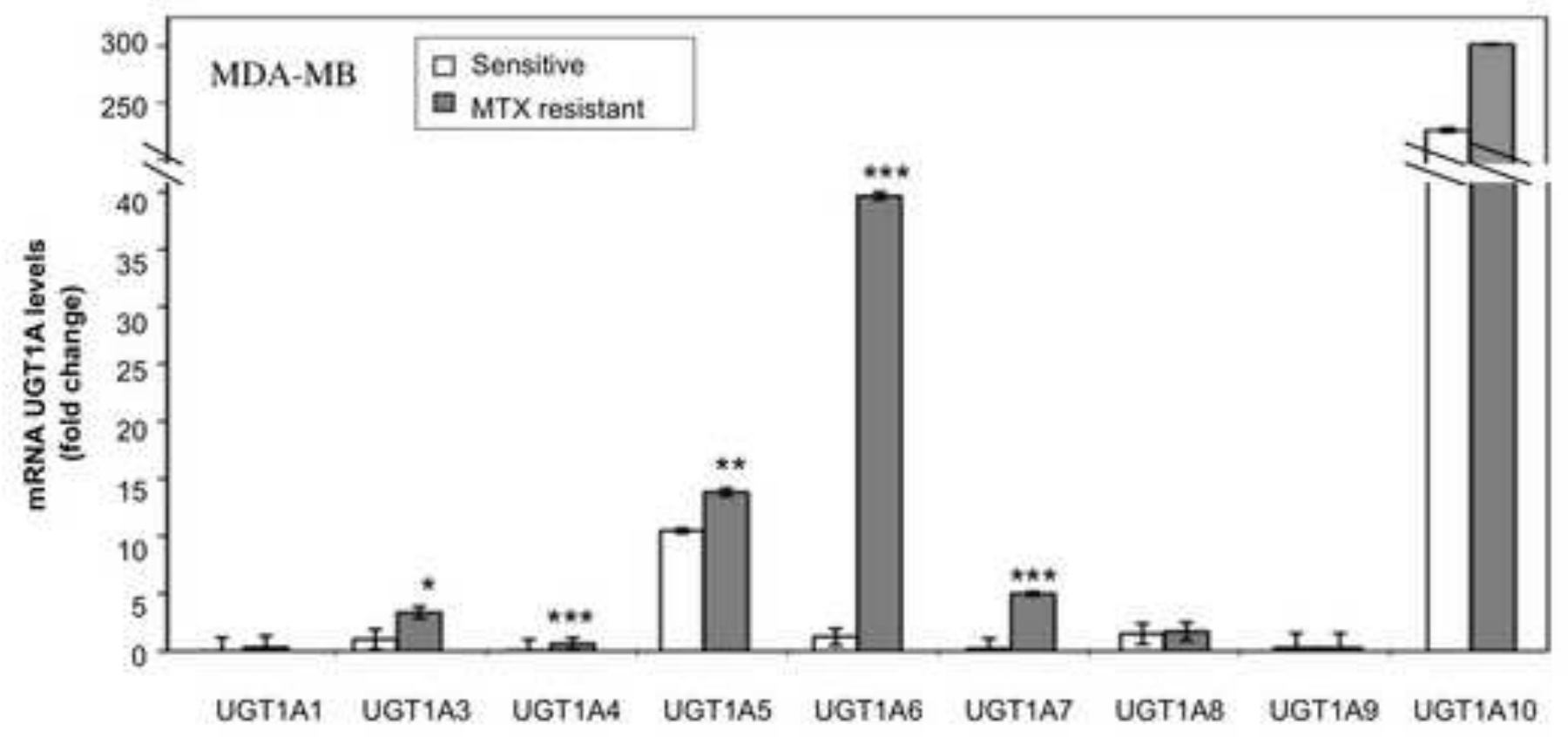


2A
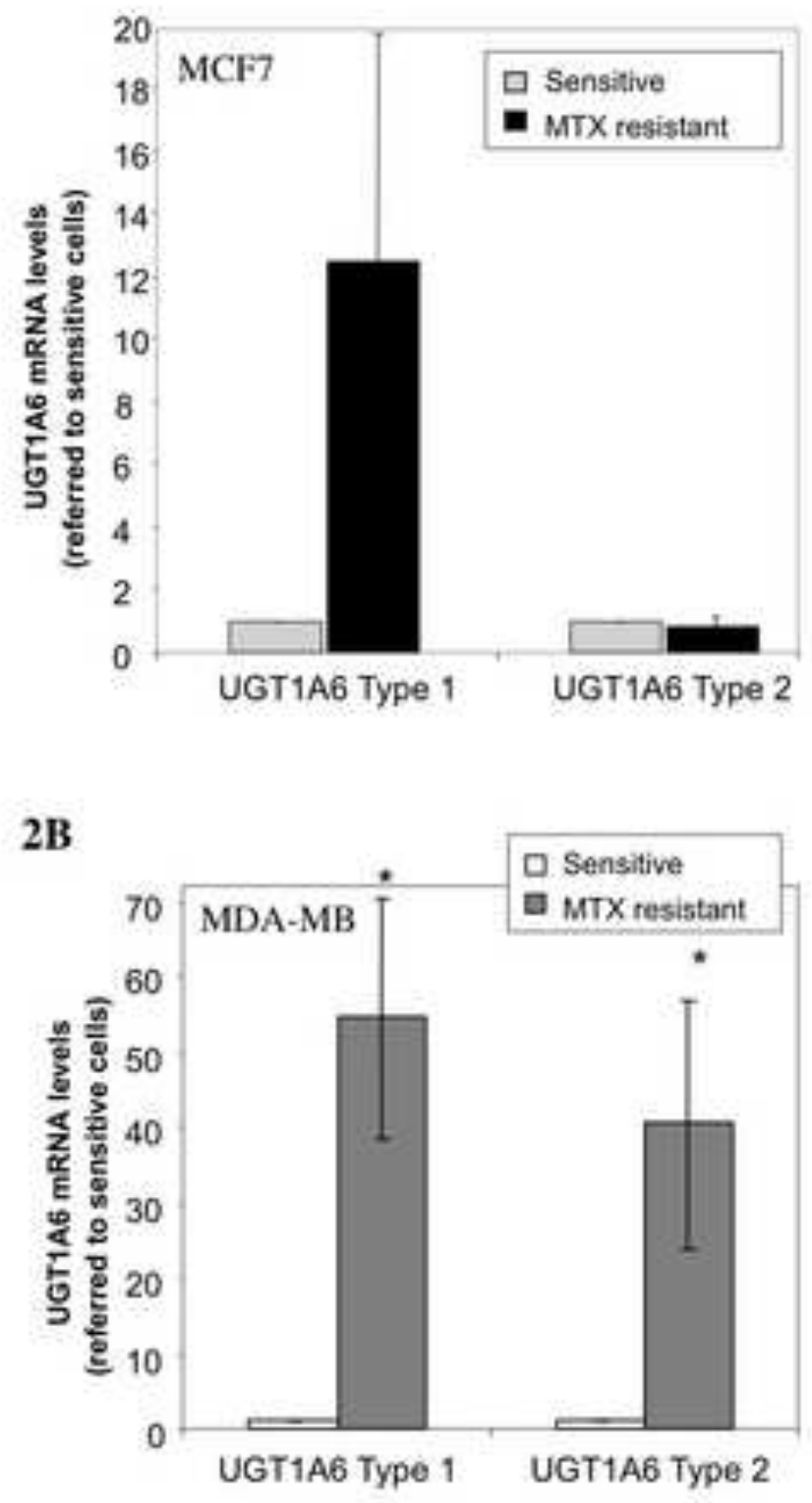

2C

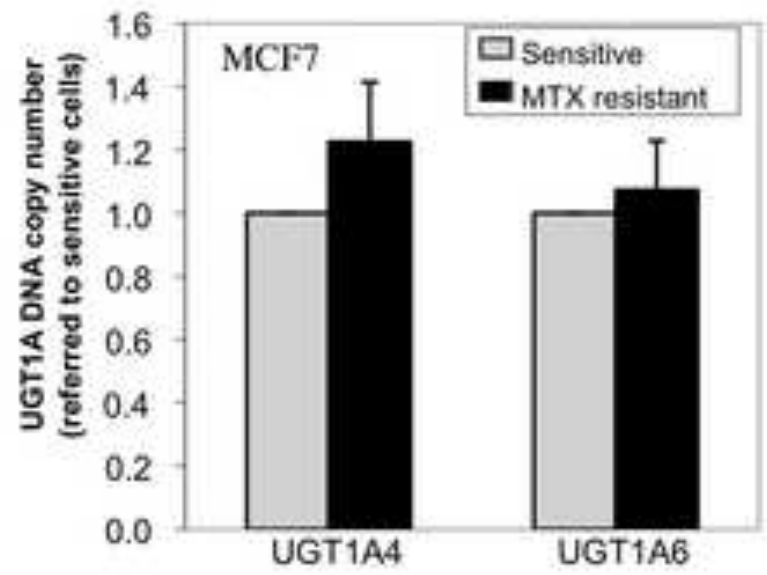

2D

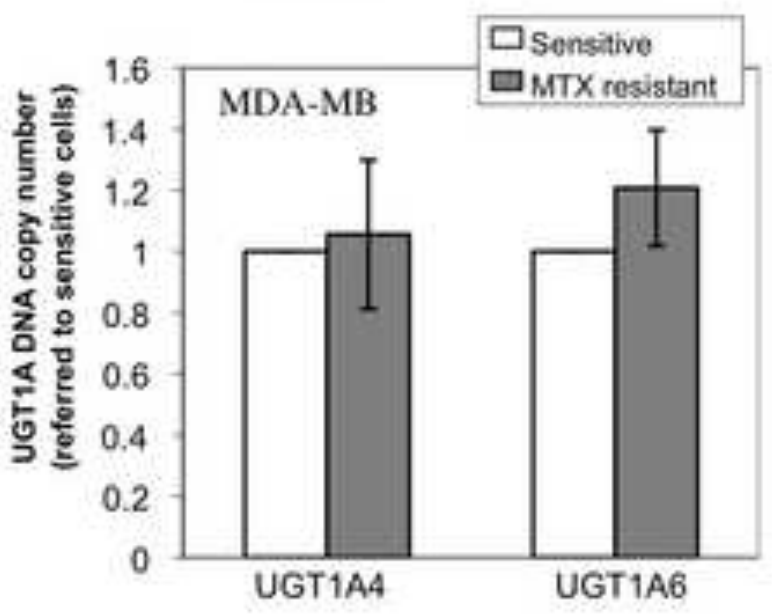

2E

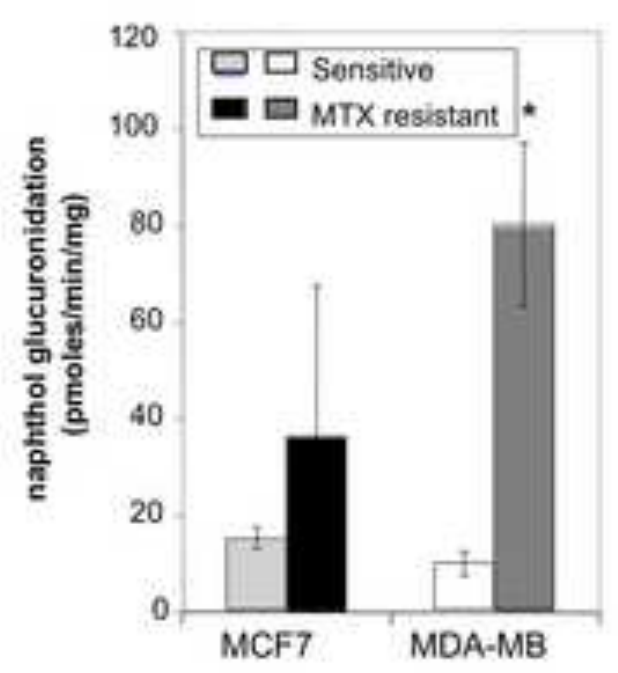


3A

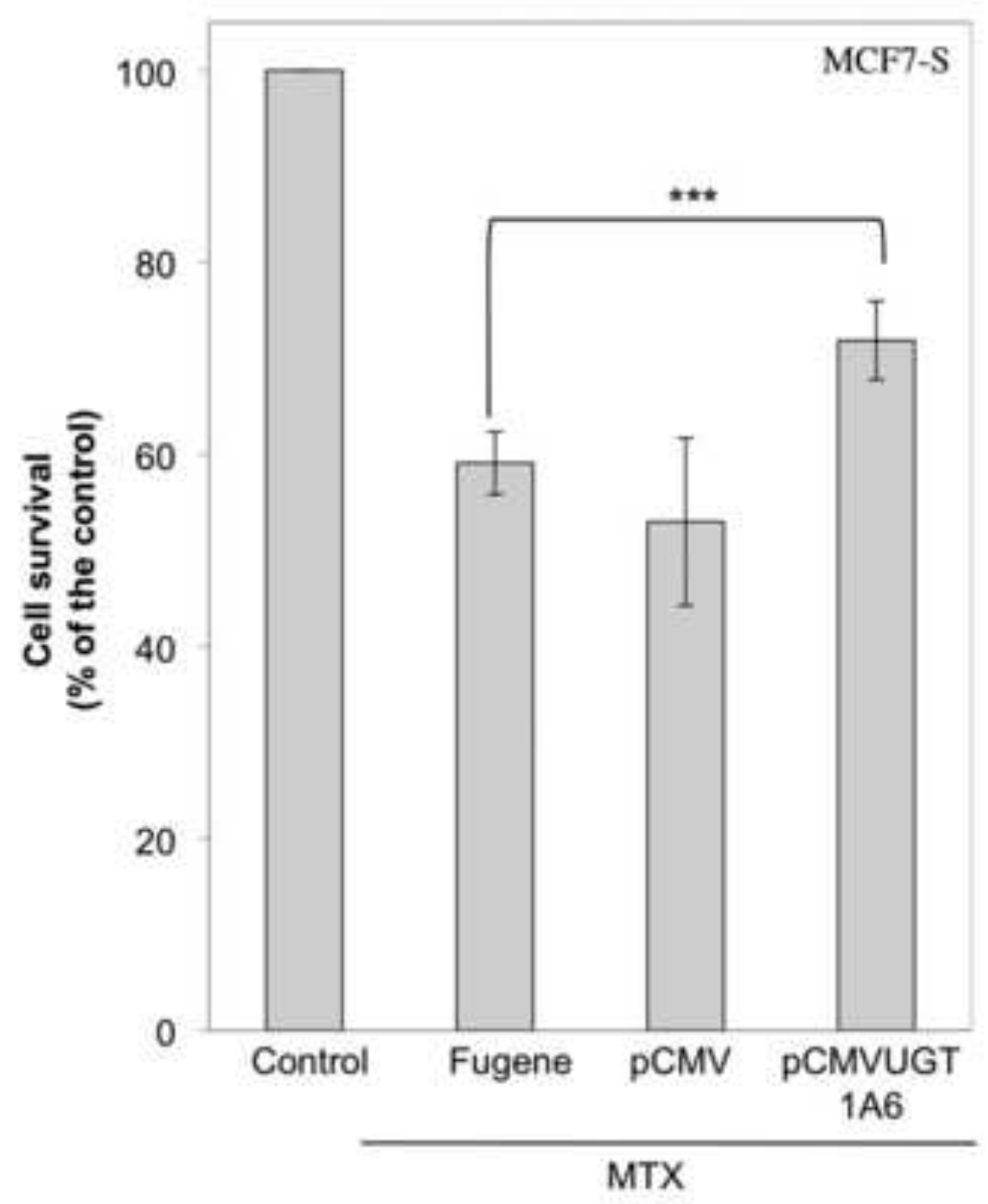

3B

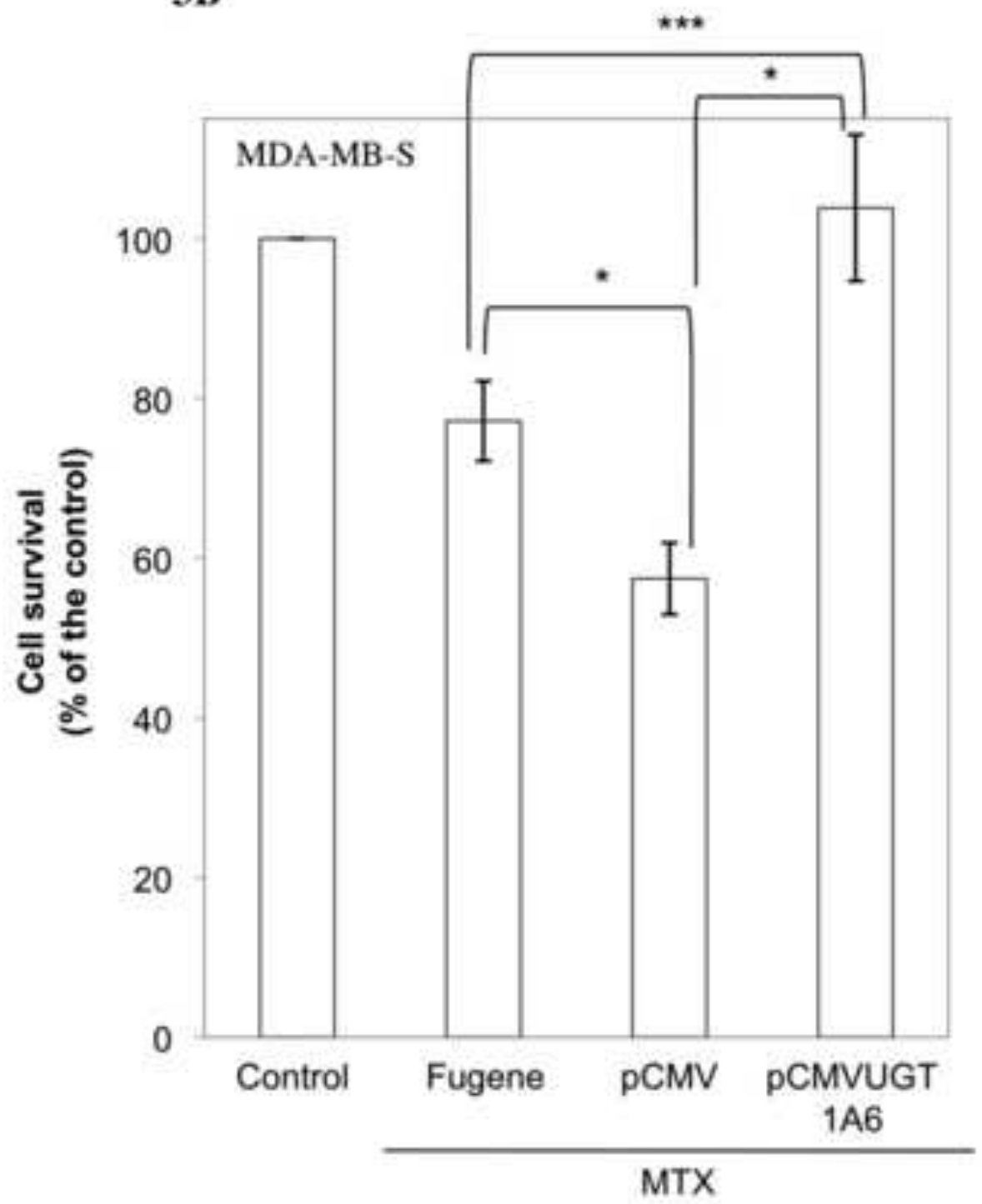


4A

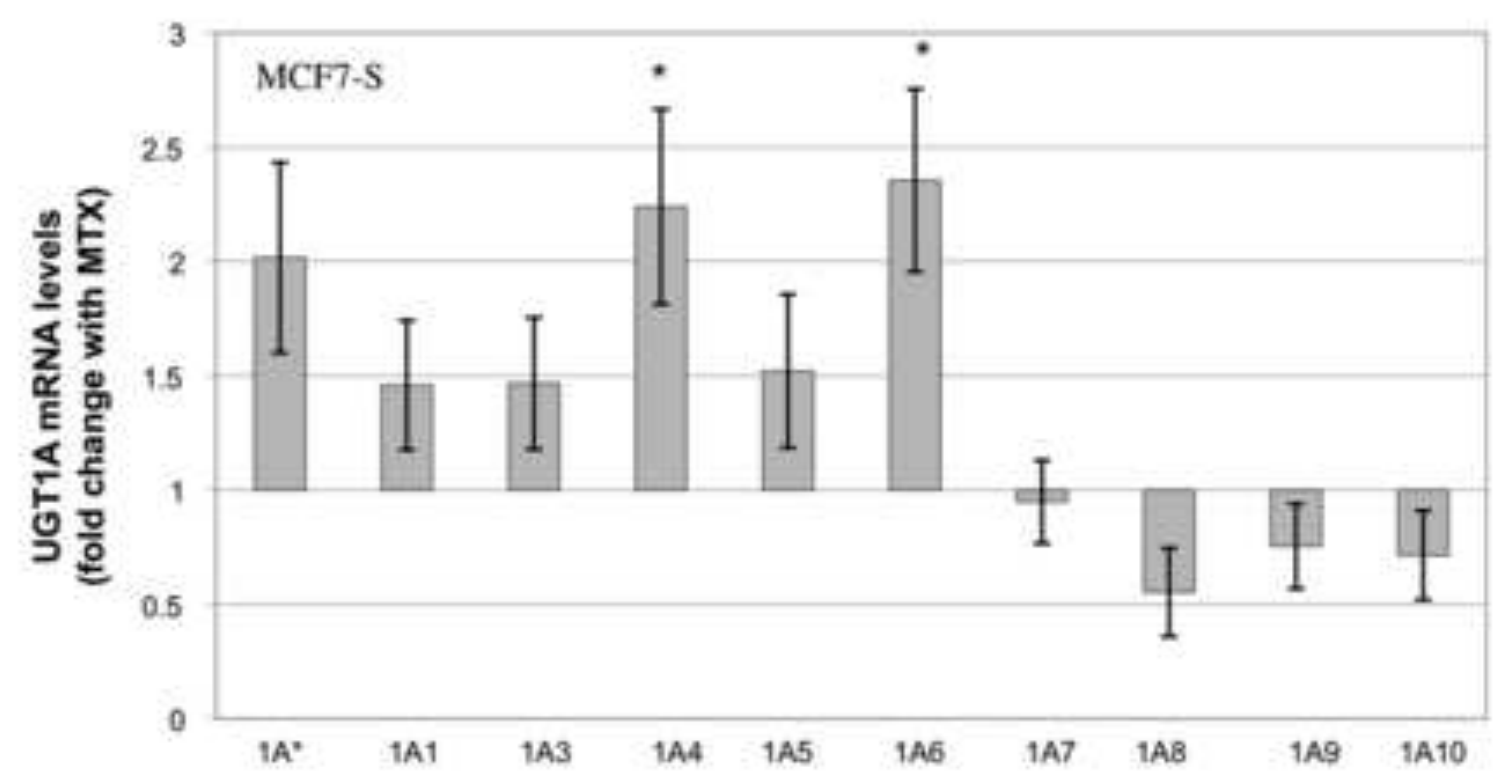

$4 \mathrm{~B}$
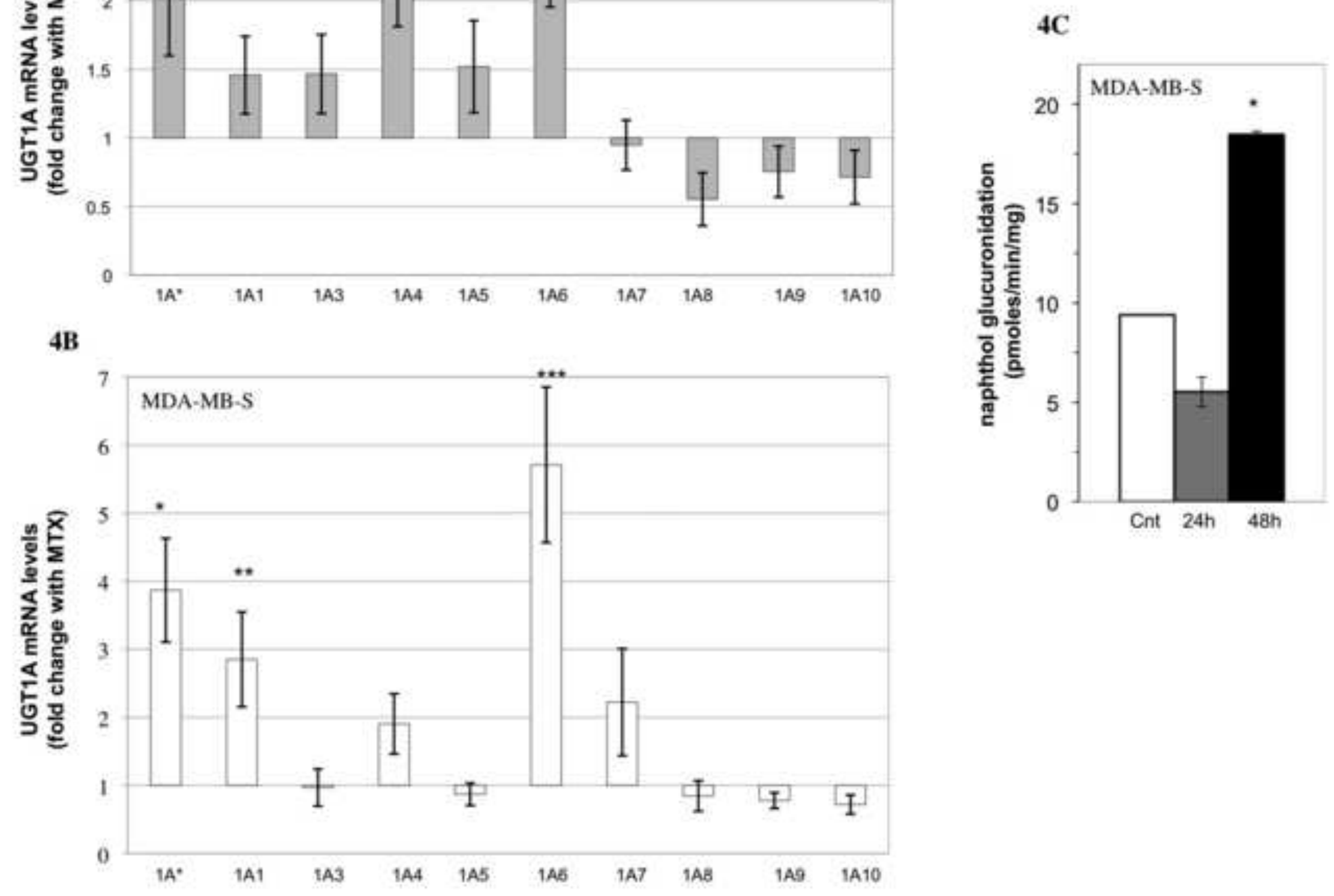


\section{A}
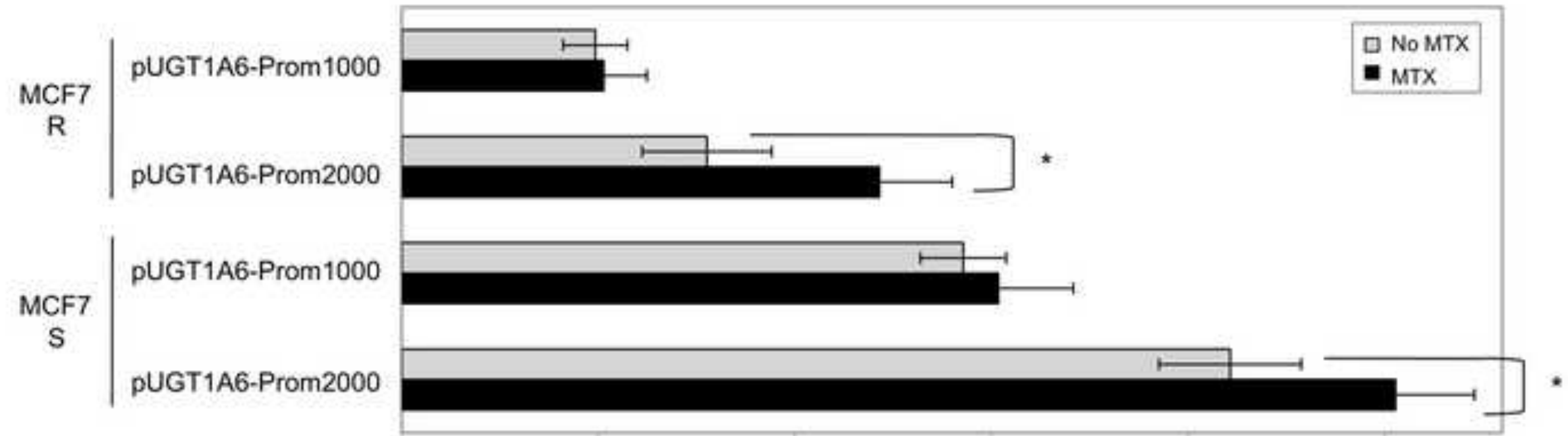

5B

0

0.5

1

1.5

2

2.5

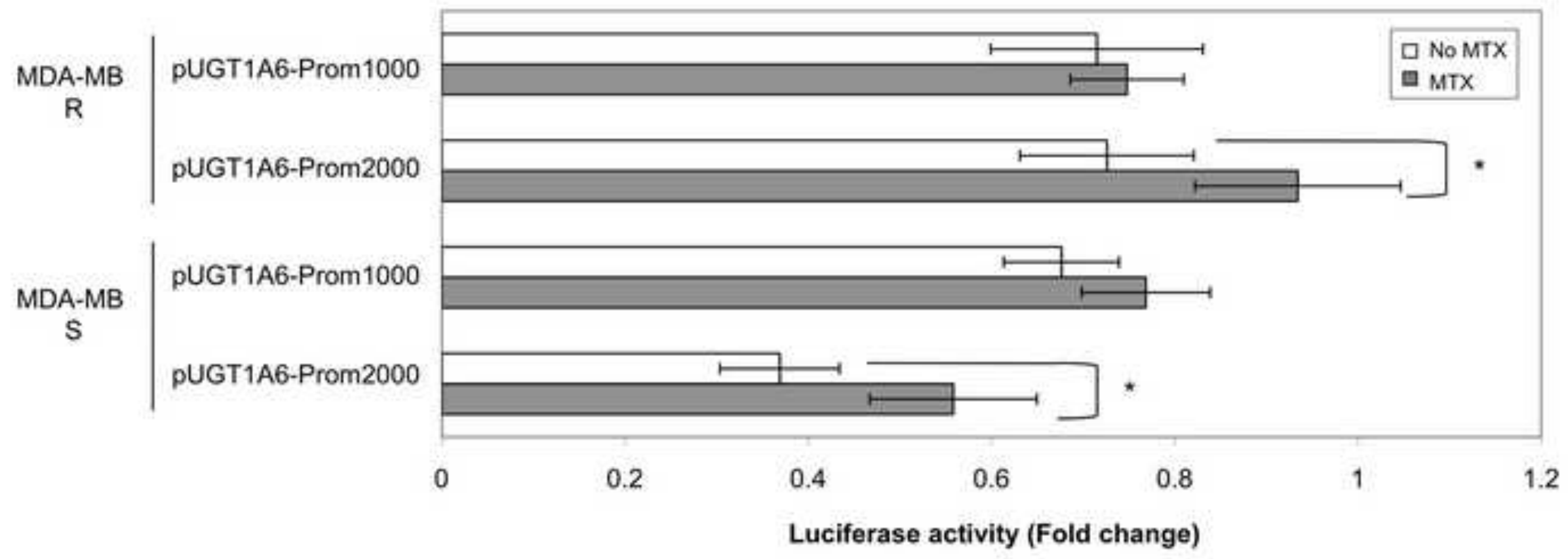

Page 38 of 44 
6A

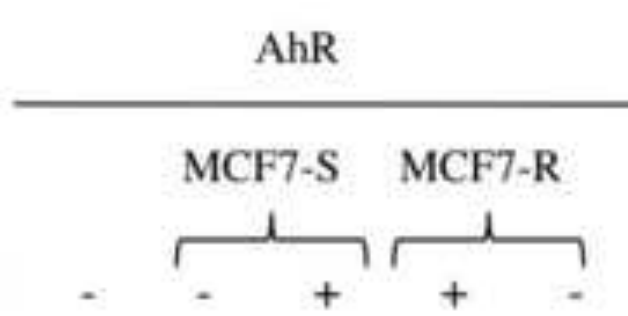

NE

$\begin{aligned} & \text { Gel-Shift } \rightarrow \\ & \rightarrow\end{aligned}$

Probe
AhR

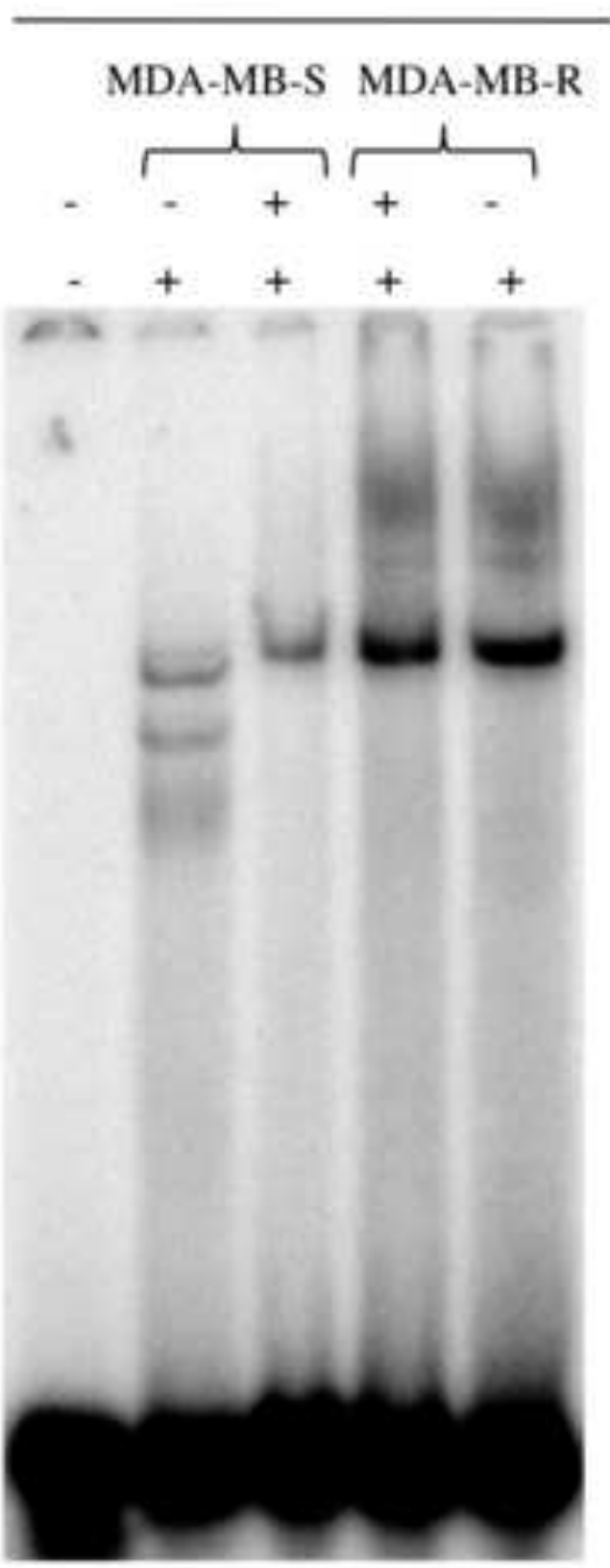

6B

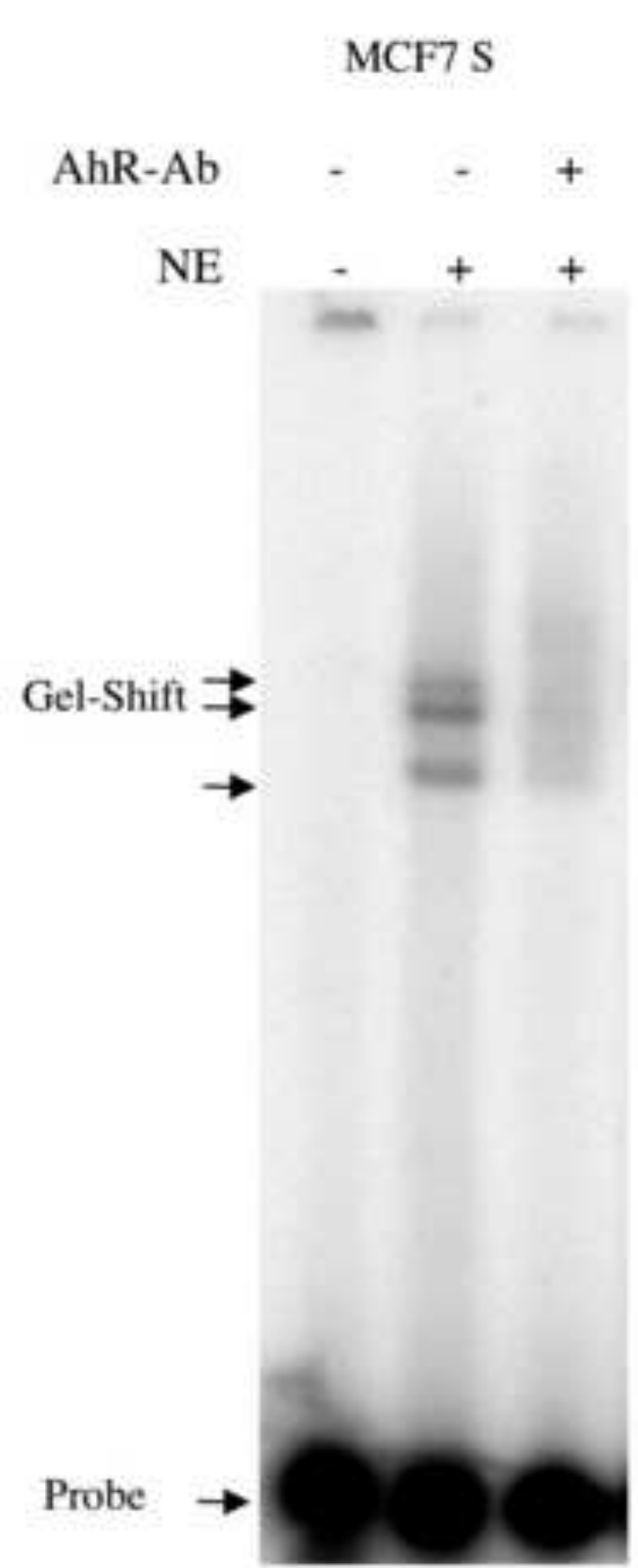


7A

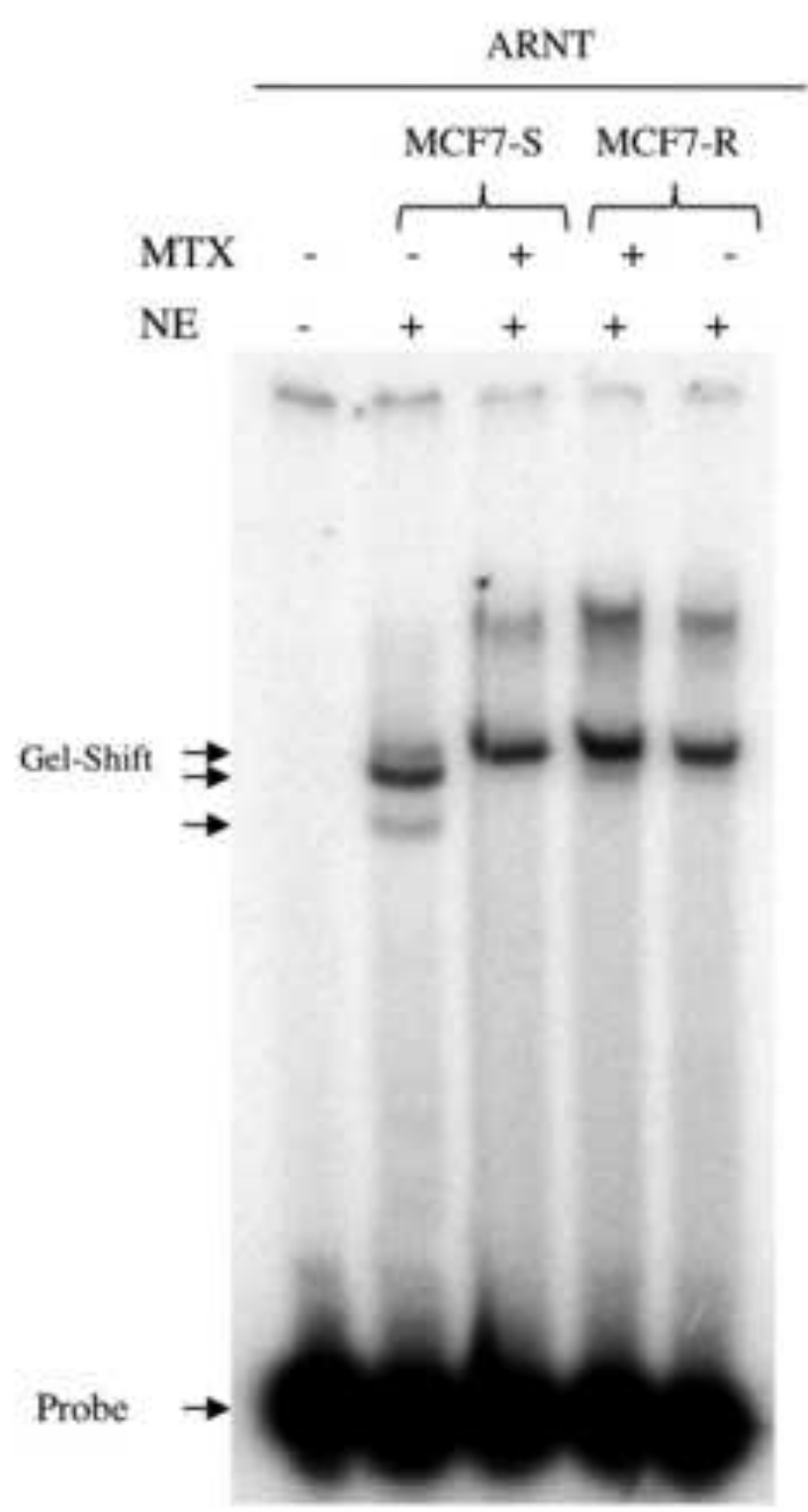

7B

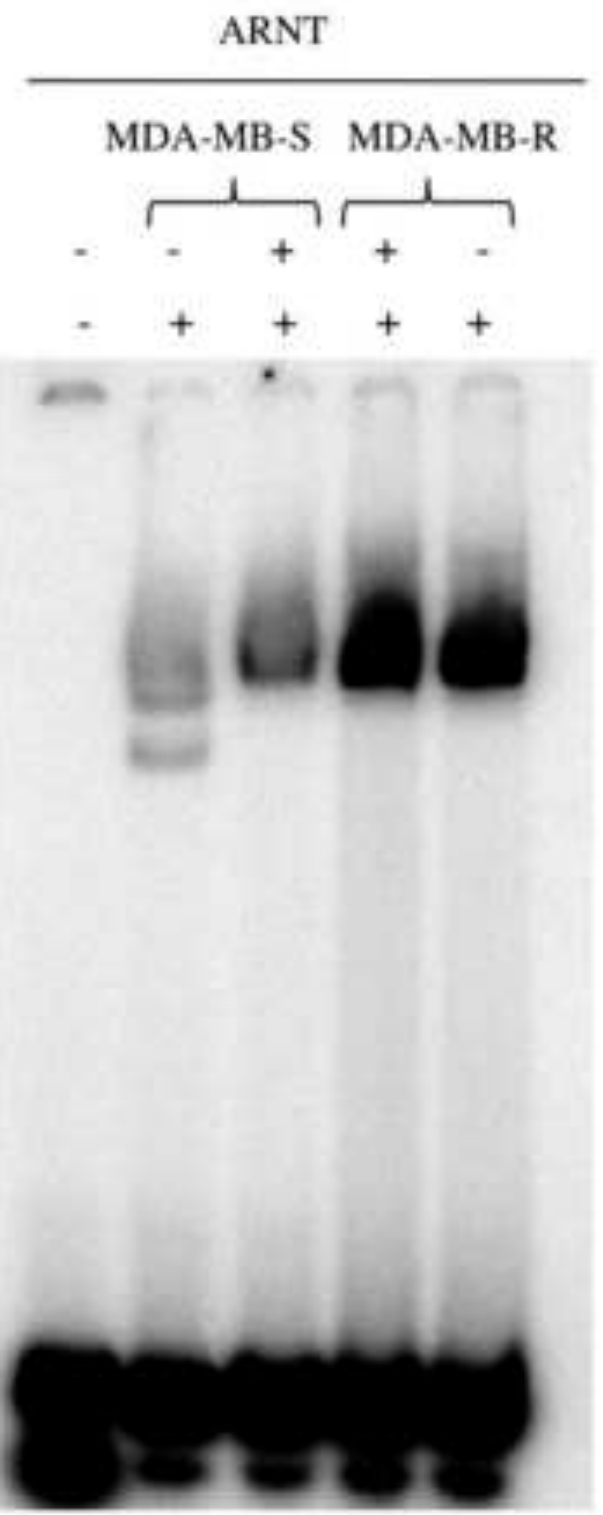

MCF7 S

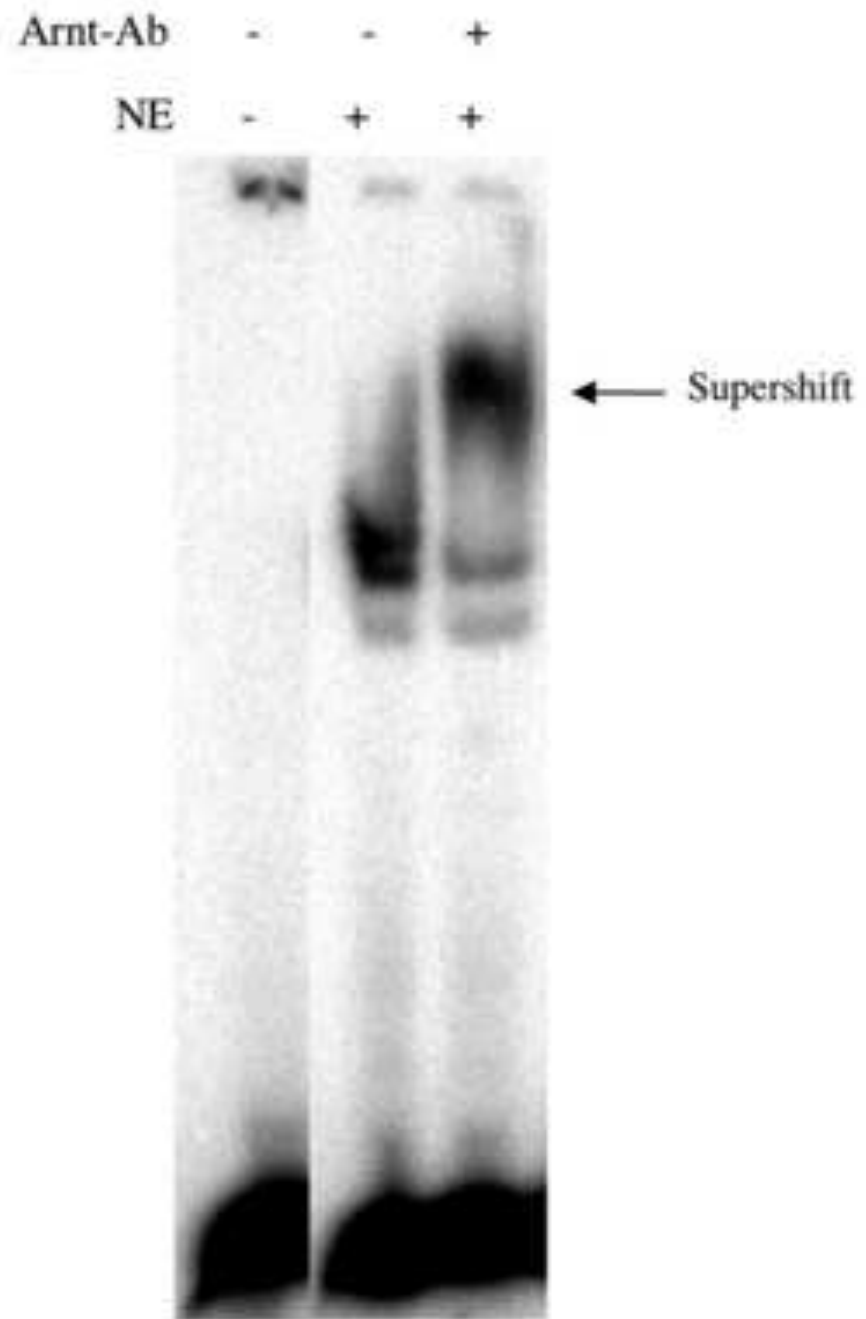


Click here to download high resolution image

8A

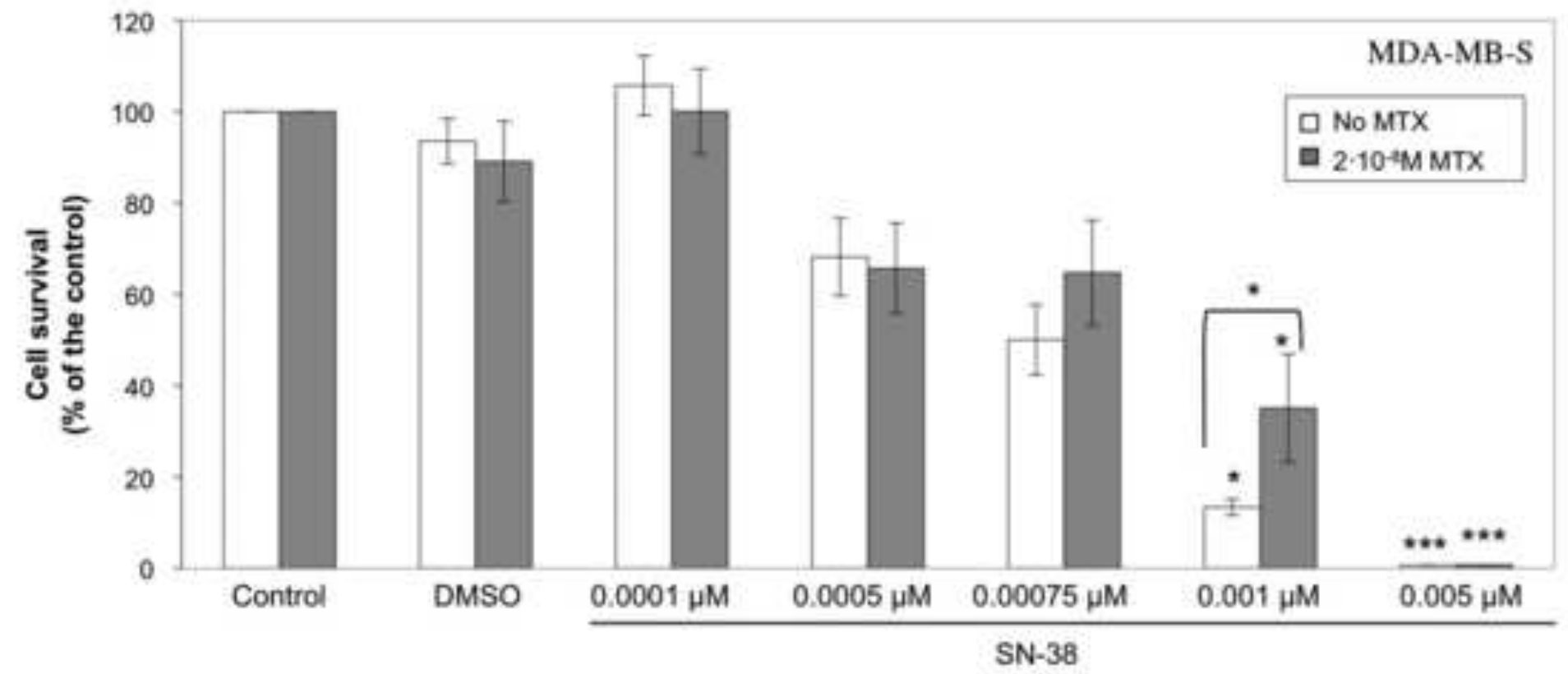

8B

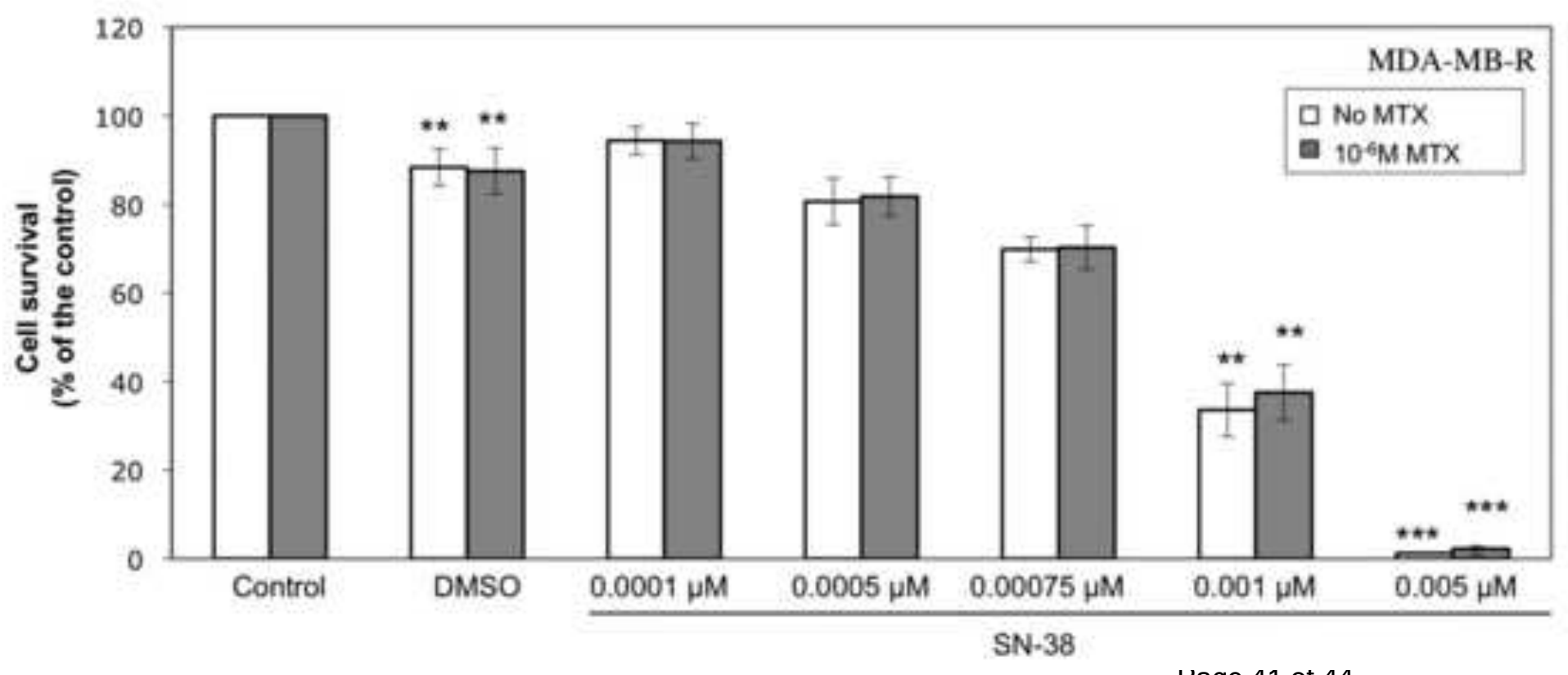

rage 41 or 44 
9A

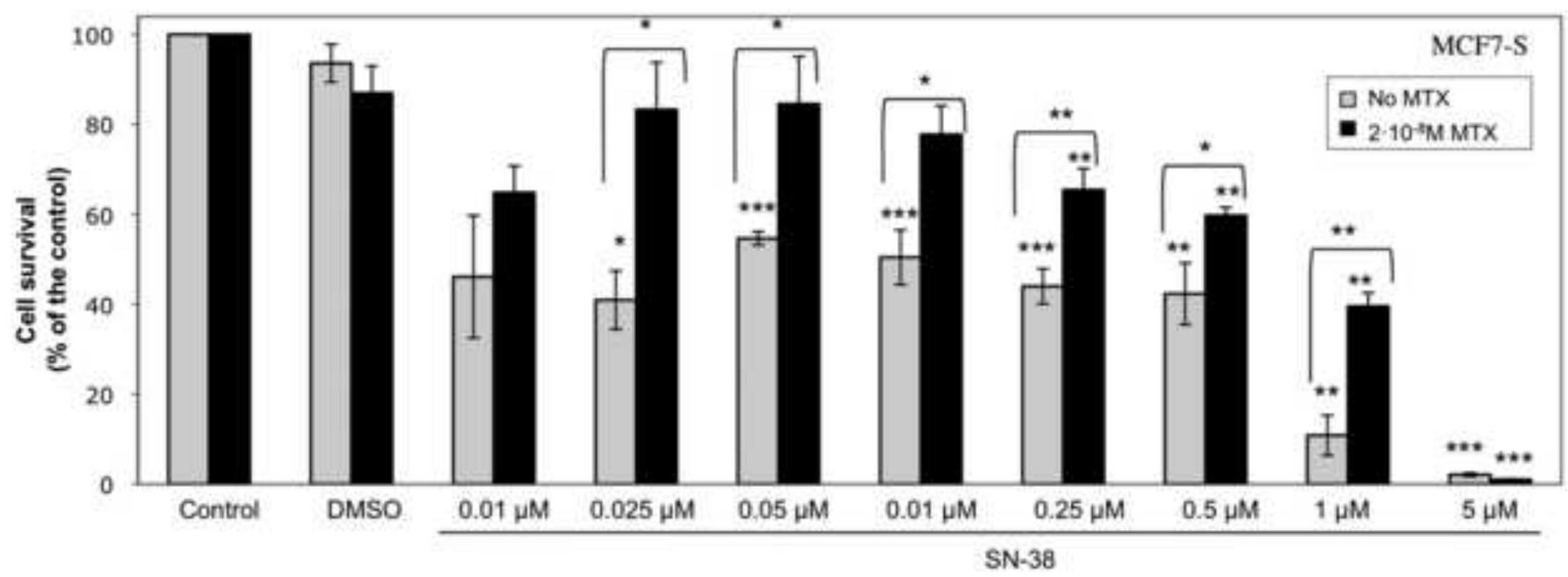

9B

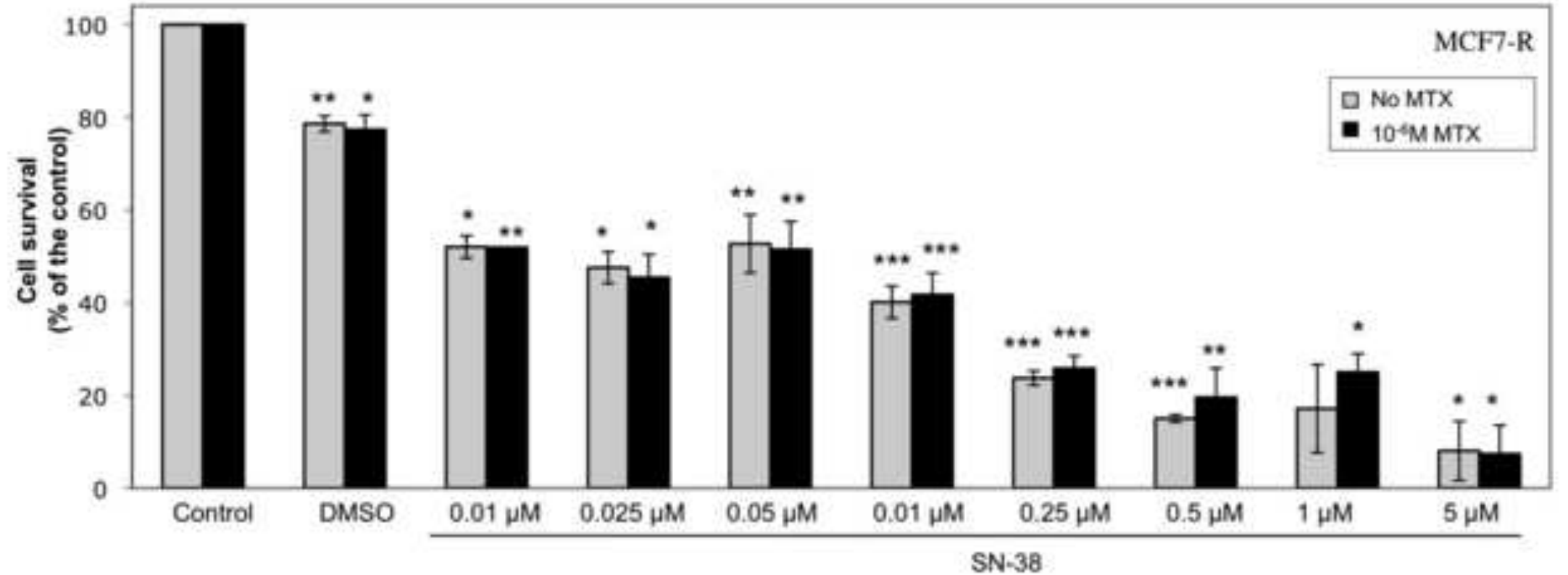

rage $4 \angle$ ot 44 


\section{$10 \mathrm{~A}$}

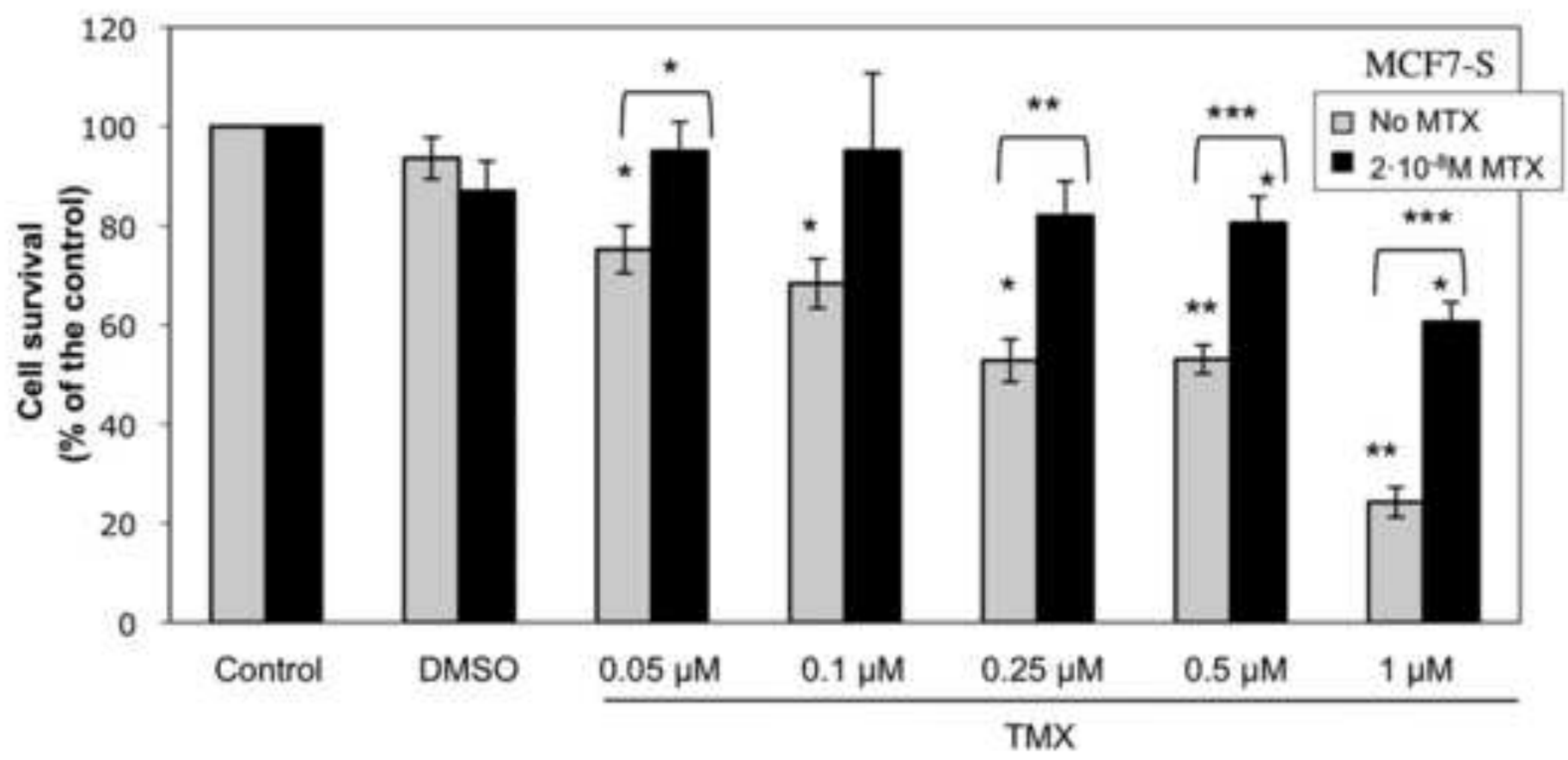

10B

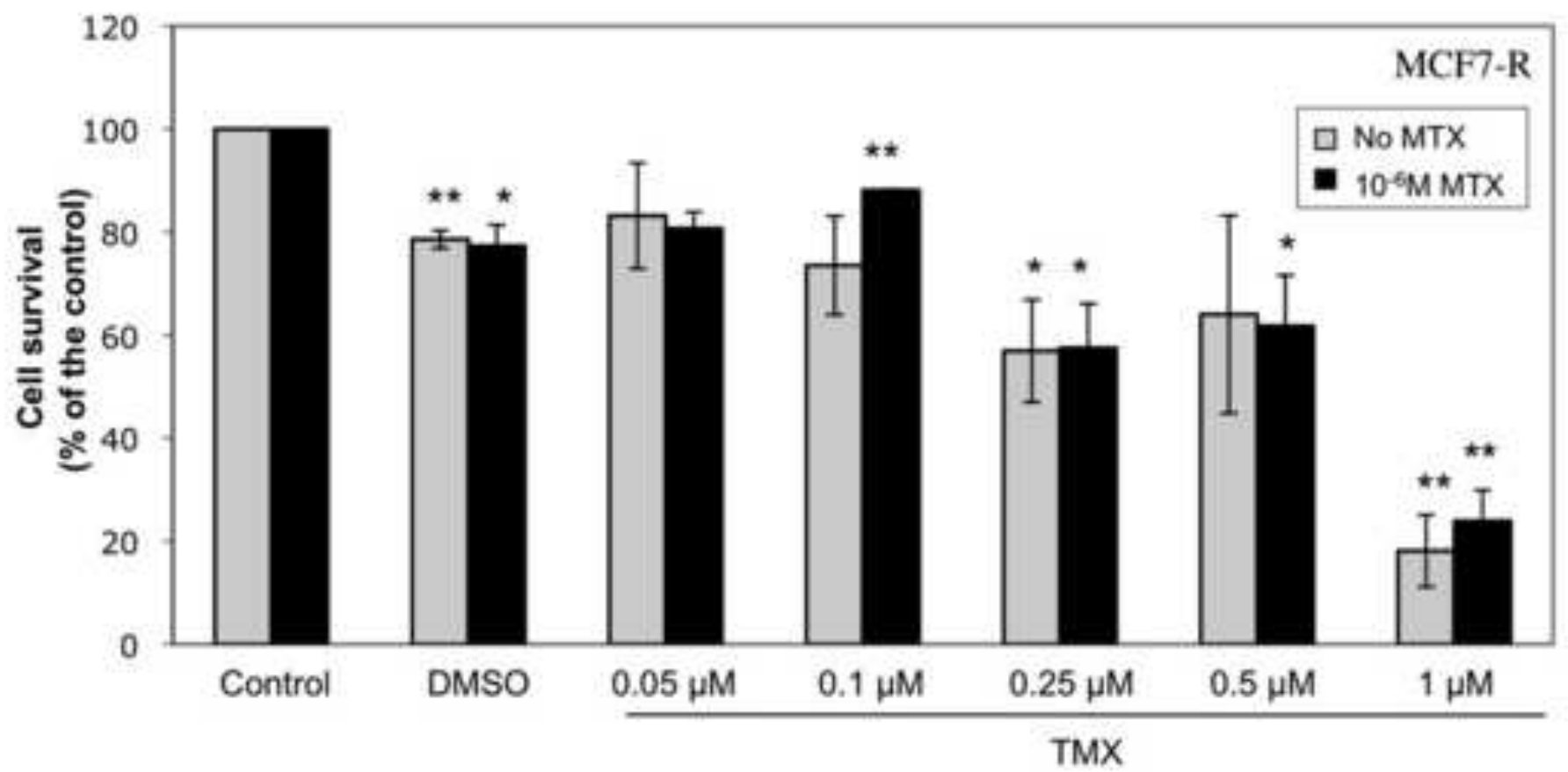


Click here to download high resolution image

Induction of UGTIA mRNA and activity caused by methotrexate in breast cancer cells
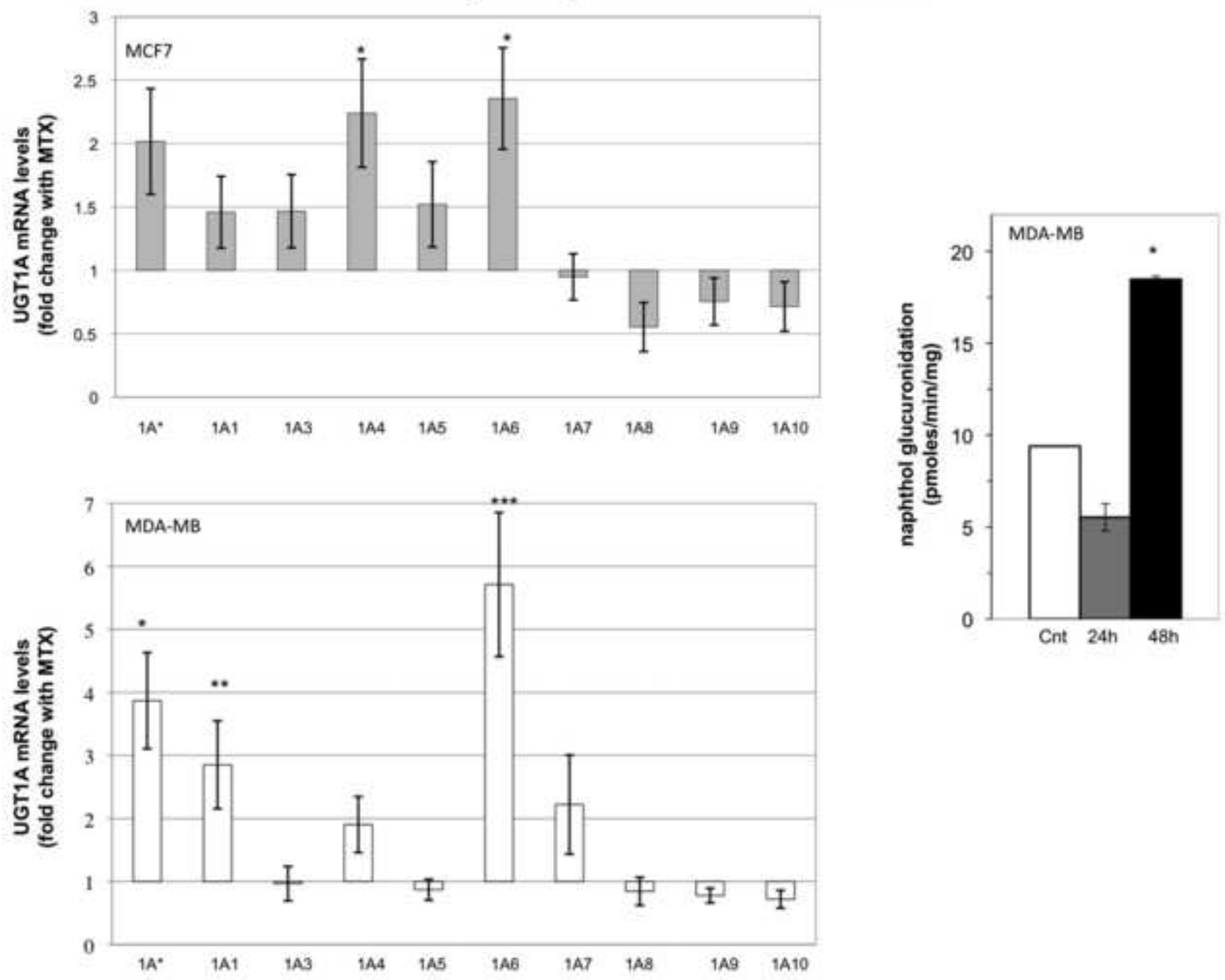

rage 44 or 44 